\title{
Synthesis, density functional theory study and in vitro antimicrobial evaluation of new benzimidazole Mannich bases
}

\author{
Maria Marinescu ${ }^{1^{*}}$ D , Ludmila Otilia Cinteză ${ }^{2}$, George luliu Marton ${ }^{3}$, Mariana-Carmen Chifiriuc ${ }^{4,5}$, \\ Marcela Popa ${ }^{4,5}$, loana Stănculescu ${ }^{2}$, Christina-Marie Zălaru ${ }^{1}$ and Cristina-Elena Stavarache ${ }^{6}$
}

\begin{abstract}
The tri-component synthesis of novel chiral benzimidazole Mannich bases, by reaction between benzimidazole, aqueous 30\% formaldehyde and an amine, the biological evaluation and DFT studies of the new compounds are reported here. The ${ }^{1} \mathrm{H}-\mathrm{NMR},{ }^{13} \mathrm{C}-\mathrm{NMR}$, FTIR spectra and elemental analysis confirm the structures of the new compounds. All synthesized compounds were screened by qualitative and quantitative methods for their in vitro antibacterial activity against 4 bacterial strains. DFT studies were accomplished using GAMESS 2012 software and HOMO-LUMO analysis allowed the calculation of electronic and structural parameters of the chiral Mannich bases. The geometry of 1-methylpiperazine, the cumulated Mullikan atomic charges of the two heteroatoms and of the methyl, and the value of the global electrophilicity index ( $\omega=0.0527$ ) of the $\mathbf{M}-\mathbf{1}$ molecule is correlated with its good antimicrobial activity. It was found that the presence of saturated heterocycles from the amine molecule, 1-methyl piperazine and morpholine, respectively, contributes to an increased biological activity, compared to aromatic amino analogs, diphenylamino-, 4-nitroamino- and 4-aminobenzoic acid. The planarity of the molecules, specific bond lengths and localization of HOMO-LUMO orbitals is responsible for the best biological activities of the compounds.
\end{abstract}

Keywords: Benzimidazole, Mannich base, Synthesis, DFT study, Antimicrobial activity, Biofilm

\section{Introduction}

Mannich bases result from a three-component condensation between a substrate with acidic hydrogen, an aldehyde and an amine. Heterocycles Mannich bases are remarkable compounds with various medicinal properties such as: antimicrobial [1-8], anticancer [9, 15], antiviral $[9,10]$, analgesic [11-13], anticonvulsant [2, 10] anti-inflammatory [11-14], anti-HIV $[2,10]$, antimalarial [15], anti-Alzheimer [16, 17], anthelmintic [15],

\footnotetext{
*Correspondence: maria.marinescu@chimie.unibuc.ro; maria7marinescu@yahoo.com; ocinteza@gw-chimie.math.unibuc.ro ${ }^{1}$ Department of Organic Chemistry, Biochemistry and Catalysis, Faculty of Chemistry, University of Bucharest, Bucharest 050663, Romania ${ }^{2}$ Department of Physical Chemistry, Faculty of Chemistry, University of Bucharest, Bucharest 030018, Romania

Full list of author information is available at the end of the article
}

antioxidant $[16,17]$ and so forth. Recent studies show Mannich bases as multifunctional agents against Parkinson disease, with good in vitro anti-inflammatory and neuroprotective effects [18]. Also, 1,2,4-triazole-adamantyl N-Mannich bases were reported for their in vivo hypoglycemic and in vitro antimicrobial activities [19].

Benzimidazole scaffold is a key pharmacophore in modern drug discovery [20], and its derivatives represent important bioactive molecules [6] with privileged structures in medicinal chemistry [21]. This can be very well confirmed by the increasing number of synthesized compounds which contain the benzimidazole moiety, with a wider range of therapeutic properties [21,22] as well as by the attempt to synthesize benzimidazole compounds with preferential geometries possessing certain biological properties [22, 23].

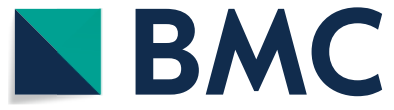

(c) The Author(s) 2020. This article is licensed under a Creative Commons Attribution 4.0 International License, which permits use, sharing, adaptation, distribution and reproduction in any medium or format, as long as you give appropriate credit to the original author(s) and the source, provide a link to the Creative Commons licence, and indicate if changes were made. The images or other third party material in this article are included in the article's Creative Commons licence, unless indicated otherwise in a credit line to the material. If material is not included in the article's Creative Commons licence and your intended use is not permitted by statutory regulation or exceeds the permitted use, you will need to obtain permission directly from the copyright holder. To view a copy of this licence, visit http://creativeco mmons.org/licenses/by/4.0/. The Creative Commons Public Domain Dedication waiver (http://creativecommons.org/publicdomain/ zero/1.0/) applies to the data made available in this article, unless otherwise stated in a credit line to the data. 
A large number of benzimidazole compounds have been employed as candidates for the treatment of various types of diseases or as clinical drugs, including anticancer agents (Pracinostat, Bendamustine), antihistamine agents (Astemizole), anthelmintic agents (Albendazole, Mebendazole) [20, 22], antibacterial agents (Ridinazole), antihypertensive agents (Candesartan), proton pump inhibitors (Pantoprazole, Ilaprazole), antiviral agents (Samatasvir) and phosphodiesterase inhibitors (Adibendan) (Fig. 1).

Benzimidazole derivatives developed a considerable interest in medical domain due to their therapeutic action as antitumor [24-33], antimicrobial [6, 34-38], anthelmintic [39, 40], proton pump inhibitors [22, 41], antiinflammatory [42, 43] and anti-hypertensive [44] drugs. Astemizole-related compounds demonstrated anti-prion activity for treatment of Creutzfeldt-Jakob disease, while albendazole compounds are currently used as medication for the treatment of a variety of parasitic worm infestations. Benzimidazoles treat mitochondrial dysfunction in Alzheimer disease [45], possess neurotropic, psychoactive, analgesic effects [46], anticoagulant proprieties [47] and are efficient agents in diabetes mellitus [48]. Benzimidazole derivatives were reported as potential EGFR and erbB2 inhibitors $[49,50]$, DNA/RNA binding ligands $[51,52]$ and antiquorum-sensing agents [53].

Chiral benzimidazole derivatives with excellent preclinical in vitro ADME were screened as $\mathrm{Na}_{V} 1.8$ (Voltage-gated sodium channels) blockers [54]. Benzimidazole compounds proved to be anti-HIV-1 agents through the protection of APOBEC3G protein [55]. Antioxidant activity was reported for benzimidazoles grafted with aromatic nuclei [56].<smiles>CCCSc1ccc2[nH]c(NC(=O)OC)nc2c1</smiles>

Albendazole (Antihelmintic)<smiles>COc1ccc(CCN2CCC(Nc3nc4ccccc4[nH]3)CC2)cc1</smiles>

Astemizole (Antihistaminic)<smiles>CCOc1nc2cccc(C(=O)O)c2n1Cc1ccc(-c2ccccc2-c2nnn[nH]2)cc1</smiles>

Candesartan (Antihypertensive)<smiles></smiles>

(Antiviral)<smiles>COC(=O)Nc1nc2cc(C(=O)c3ccccc3)ccc2[nH]1</smiles>

Mebendazole (Antihelmintic)<smiles>CCCCc1nc2cc(/C=C/C(=O)NO)ccc2n1CCN(CC)CC</smiles>

Pracinostat (Anticancer)<smiles>COc1ccnc(CS(=O)c2nc3ccc(OC(F)F)cc3[nH]2)c1OC</smiles>

Pantoprazole (Proton pump inhibitor)

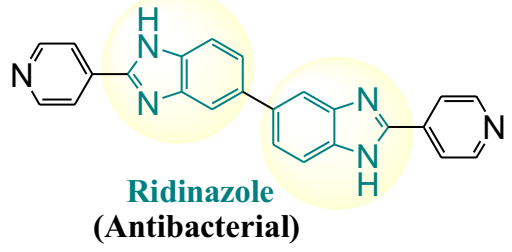<smiles>Cn1c(CCCC(=O)O)nc2cc(N(CCCl)CCCl)ccc21</smiles>

(Anticancer)<smiles>COc1ccnc(CS(=O)c2nc3cc(-n4cccc4)ccc3[nH]2)c1C</smiles>

Ilarazole

(Proton pump inhibitor)<smiles>CC1(C)C(=O)Nc2cc3nc(-c4ccncc4)[nH]c3cc21</smiles>

Adibendan (Phosphodiesterase inhibitor)

Fig. 1 The structures of some representative benzimidazole based drugs 
Recent literature mentions a series of syntheses of Mannich chiral bases, predominantly by classical procedures and less by green methods. Referring to classical procedures, Bernardi et al. studied the catalytic asymmetric Mannich reactions for the synthesis of optically active $\alpha, \beta$-diamino acid derivatives [57] while Ibrahem and Guo groups used the chiral aminoacids for the direct asymmetric three-component Mannich reaction [58, 59]. Bhadury and Song reviewed the mechanism and the stereochemistry of organocatalytic asymmetric Mannich reactions [60], Cai and Xie provide an overview of asymmetric Mannich reactions with different organocatalysts, such as: chiral Brønsted acids, chiral amines, chiral bifunctional thiourea, and others [61]. In recent years, the stereoselective asymmetric Mannich reactions of aldehydes catalyzed by chiral primary amine were reported by Dai et al. [62], enantioselective Mannich syntheses promoted by chiral phosphinoyl-aziridines [63], asymmetric Mannich reactions to generate chiral $\beta$-amino esters [64], and copper-catalyzed enantioselective Mannich reactions of $\mathrm{N}$-acylpyrazoles and isatin [65].

Among the green methods of asymmetric Mannich syntheses, we can mention protease-catalysed direct reaction in acetonitrile [66], N,N'-dioxide metal complexes-catalysed reaction in dichloromethane [67] and synthesis of $\beta$-amino carbonyl compounds using maleic acid in ethanol [68].

Antibiotics have been considered one of the most important discoveries in the early part of the last century, being very effective in controlling bacterial infections, but their inappropriate use has rapidly led to the emergence of antibiotic-resistant pathogens. Resistance to antibiotics has been increasing in recent years and becoming a serious and global challenge to the drug discovery [69]. Nowadays there are bacteria already resistant to nearly all available antibiotics. Therefore, there is a growing interest in the finding of new, effective antibiotics [70, 71].

It was stated that the planarity of the compound and symmetry of the molecule are advantages for a high antimicrobial activity [6]. Other authors find that low polarity of molecules is an advantage for antimicrobial activity [37]. Also, antimicrobial activity is correlated with the presence of functional groups such as, benzimidazole esters as antifungal agents [72] and amino for antimicrobial activity [73].

Based on our previous findings on good microbial activity, correlated with compound structure [6], in this study propose directed synthesis of some benzimidazole Mannich bases, the screening of their antimicrobial activity, density functional theory study (DFT) on the synthesized structures and discussions on drug-design (Additional file 1).

\section{Results and discussion}

The synthesis of the new (S)-1-(1(alkylaminomethyl)benzo[d]imidazole-2-yl)ethanol is shown in Fig. 2. (S)-1-(1H-Benzo[d]imidazole-2-yl)ethanol B was synthesized according to the procedure described in our previous work [6]. The novel bases M-1-M-5 (Fig. 3) were obtained by the classical Mannich reaction, at reflux temperature, as a three component condensation between benzimidazole B, aqueous 30\% formaldehyde and an amine reagent [7]. The syntheses afford good yields (73-83\%). The hydrogen atom of the imino group of benzimidazole $\mathbf{B}$ is quite active to participate in Mannich reactions.

In the Mannich reaction, primary or secondary amines are nucleophilic reactants for the carbonyl group of the formaldehyde [7] and the Mannich bases M-1-M-5 or

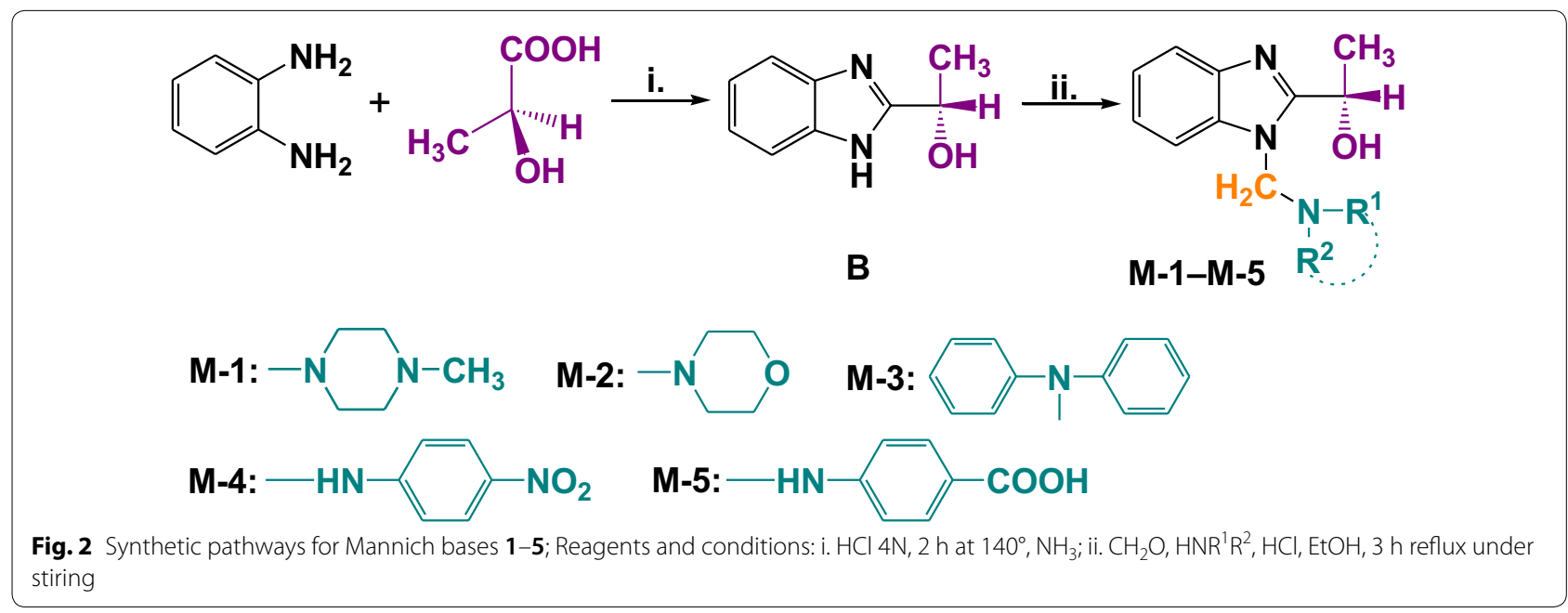


<smiles>C[C@@H](O)c1nc2ccccc2[nH]1</smiles>

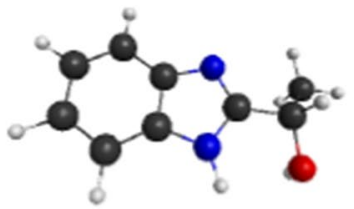

$B^{a}$<smiles>C[C@@H](O)c1nc2ccccc2n1CN1CCOCC1</smiles>

M-2<smiles>C[C@H](O)c1nc2ccccc2n1CNc1ccc([N+](=O)[O-])cc1</smiles>

M -4<smiles>CN1CCN(Cn2c(C(C)(O)O)nc3ccccc32)CC1</smiles>

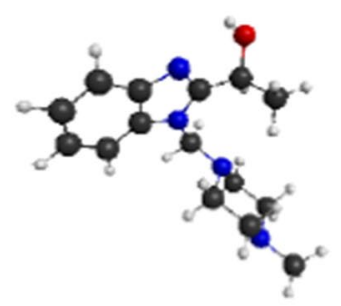

$M-1$<smiles>C[C@@H](O)c1nc2ccccc2n1CN(c1ccccc1)c1ccccc1</smiles>

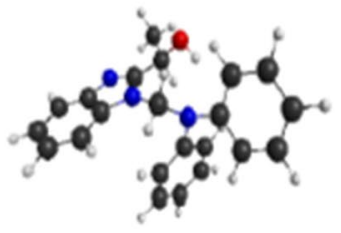

M-3<smiles>C[C@@H](O)c1nc2ccccc2n1CNc1ccc(C(=O)O)cc1</smiles>

M-5

Fig. 3 The structure formulas and the DFT optimized structures of benzimidazole $\mathbf{B}$ and Mannich bases $\mathbf{M}-\mathbf{1}-\mathbf{M}-\mathbf{5}$ (black-C; grey-H; red-O; blue-N). For interpretation of the references to colour in this figure legend, the reader is referred to the web version of this article. ${ }^{\text {a}}$ From Ref. [6]

$\beta$-amino-carbonyl compounds are the final products of this condensation reaction.

Determination of the optical purity of compounds $\mathbf{B}$, M-1-M-5 was done by HPLC analysis using a CHIRALPAK column. All the benzimidazoles were found to have enantiomeric excess $>90 \%$. All benzimidazole structures were confirmed by spectroscopic methods: ${ }^{1} \mathrm{H}-\mathrm{NMR}$, ${ }^{13} \mathrm{C}-\mathrm{NMR}$, FTIR, MS and elemental analysis. The main features of the ${ }^{1} \mathrm{H}-\mathrm{NMR}$ spectra of the compounds $\mathbf{M}-\mathbf{1}-$ M-5 are the signals corresponding to the methylene protons directly bonded to both amine nitrogen atom and heterocyclic nitrogen atom which appears in the range 5.1-6.01 ppm [74, 75]. The most shielded methylene protons were observed in case of M-3 Mannich base due to the simultaneous presence of the two aromatic nuclei, linked by the amine group. The hydrogen atoms in the benzimidazole moiety appear at the expected values of 7.11-7.74 ppm. The presence of substituents at the nitrogen atom of the Mannich bases does not greatly affect the chemical shifts of benzimidazole aromatic protons. The proton of the hydroxyl group constantly appears at
5.72-5.79 ppm and the methine group - as a quartet-at 4.92-4.94 ppm.

The ${ }^{13} \mathrm{C}$-NMR spectra confirm the structure of the Mannich bases obtained by amino alkylation. The methyl group of 2-hydroxyethylbenzimidazole appears at 21-23 ppm. The most shielded aliphatic signal corresponding to Mannich methylene group appears at $61 \mathrm{ppm}$ for the Mannich bases obtained with aliphatic amines M-1 and M-2 and at around 81 ppm for the Mannich bases with aromatic amines $\mathbf{M - 3}-\mathbf{M}-\mathbf{5}$. The aromatic carbon atoms in the benzimidazole moiety appear in the expected ranges.

The MS spectra of all Mannich bases confirmed the presence of the molecular ions.

FTIR spectra show the stretching bands characteristic to the tertiary aromatic amines in the range 1143$1360 \mathrm{~cm}^{-1}$ for the compounds M-1-M-5. The presence of a methylene Mannich group was confirmed by a strong signal in range of $1457-1530 \mathrm{~cm}^{-1}$ of the bending vibration $\delta\left(\mathrm{CH}_{2}\right)$. A broad band in the range 3200$3570 \mathrm{~cm}^{-1}$ was assigned to $v(\mathrm{OH})$ stretching vibration. 
Table 1 The antimicrobial activity of the tested compounds expressed semi-quantitatively, as the absence of the microbial growth $(-)$, slight decrease of the microbial growth $( \pm)$, total inhibition of microbial growth $(+,++)$

\begin{tabular}{|c|c|c|c|c|c|c|c|c|}
\hline Compound/Microbial tested strain & B & M-1 & M-2 & $M-3$ & $\mathrm{M}-4$ & M-5 & Erythromycin & Clotrimazole \\
\hline S. aureus ATCC 6538 & \pm & + & \pm & \pm & - & \pm & + & $\mathrm{n} / \mathrm{a}$ \\
\hline P. aeruginosa ATCC 27853 & + & + & ++ & + & - & + & ++ & $\mathrm{n} / \mathrm{a}$ \\
\hline E. coli ATCC 8739 & + & + & + & ++ & \pm & \pm & ++ & $\mathrm{n} / \mathrm{a}$ \\
\hline C. albicans ATCC 10231 & + & + & + & ++ & + & - & $\mathrm{n} / \mathrm{a}$ & ++ \\
\hline
\end{tabular}

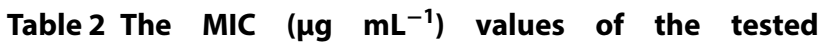
compounds against the tested microbial strains

\begin{tabular}{lllll}
\hline Compounds & $\begin{array}{l}\text { S. aureus } \\
\text { ATCC } \\
\mathbf{6 5 3 8}\end{array}$ & $\begin{array}{l}\text { P. aeruginosa } \\
\text { ATCC 27853 }\end{array}$ & $\begin{array}{l}\text { E. coli ATCC } \\
\mathbf{8 7 3 9}\end{array}$ & $\begin{array}{l}\text { C. albicans } \\
\text { ATCC } \\
\mathbf{1 0 2 3 1}\end{array}$ \\
\hline $\mathbf{B}$ & $<1$ & 0.008 & $<1$ & 0.002 \\
$\mathbf{M}-\mathbf{1}$ & $<1$ & 0.031 & 0.031 & 0.031 \\
$\mathbf{M}-\mathbf{2}$ & 0.052 & $<1$ & $<1$ & 0.032 \\
$\mathbf{M}-\mathbf{3}$ & $<1$ & $<1$ & $<1$ & 0.052 \\
$\mathbf{M}-\mathbf{4}$ & 0.030 & $<1$ & $<1$ & 0.030 \\
$\mathbf{M}-\mathbf{5}$ & $<1$ & $<1$ & $<1$ & $<1$ \\
Erythromycin & 0.062 & 0.062 & 0.062 & $\mathrm{n} / \mathrm{a}$ \\
Clotrimazole & $\mathrm{n} / \mathrm{a}$ & $\mathrm{n} / \mathrm{a}$ & $\mathrm{n} / \mathrm{a}$ & 0.031 \\
\hline
\end{tabular}

The stretching bands due of the benzimidazole ring can be found at $742-753 \mathrm{~cm}^{-1}, 1108-1213 \mathrm{~cm}^{-1}$ and 2829 $3085 \mathrm{~cm}^{-1}$ range.

\section{Antibacterial activity}

The antibacterial activity of the benzimidazole compounds has been evaluated against three bacterial strains, both Gram positive cocci, Staphylococcus aureus ATCC 6538 (S. aureus) and Gram negative bacilli: Pseudomonas aeruginosa ATCC 27853 (P. aeruginosa) and Escherichia coli ATCC 8739 (E. coli) $[6,72]$ by comparing their minimum inhibitory concentration (MIC) values against a standard drug, erythromycin.

In the qualitative assay (Table 1), from the tested compounds, the most active proved to be $\mathbf{M - 1}$, active against all four tested strains, followed by the Mannich bases M-2, M-3 and benzimidazole B, active against three of the 4 tested strains, all inhibited the growth of Gram negative strains and fungus. All compounds except $\mathbf{M}-\mathbf{5}$ have also antifungal effects. Compounds M-4 and M-5 possess a much lower antimicrobial activity, the first one only antifungal activity and the second one antibacterial activity against one Gram negative bacilli strain, $P$. aeruginosa.

All the MIC values obtained for the compounds (B, M-1-M-5) are reported in Table 2. It was observed that the DMSO solvent does not influence the antibacterial activity of the tested compounds at the working
Table 3 The MBEC ( $\mu \mathrm{g} \mathrm{mL}^{-1}$ ) values of the tested compounds against the tested microbial strains

\begin{tabular}{lllll}
\hline Compounds & $\begin{array}{l}\text { S. aureus } \\
\text { ATCC } \\
\mathbf{6 5 3 8}\end{array}$ & $\begin{array}{l}\text { P. aeruginosa } \\
\text { ATCC 27853 }\end{array}$ & $\begin{array}{l}\text { E. coli ATCC } \\
\mathbf{8 7 3 9}\end{array}$ & $\begin{array}{l}\text { C. albicans } \\
\text { ATCC } \\
\mathbf{1 0 2 3 1}\end{array}$ \\
\hline $\mathbf{B}$ & $<1$ & 0.01562 & $<1$ & 0.034 \\
$\mathbf{M - 1}$ & $<1$ & 0.01562 & 0.25 & 0.25 \\
$\mathbf{M - 2}$ & 0.25 & $<1$ & $<1$ & 0.032 \\
$\mathbf{M - 3}$ & $<1$ & $<1$ & $<1$ & $<1$ \\
$\mathbf{M - 4}$ & 0.031 & $<1$ & $<1$ & 0.030 \\
$\mathbf{M - 5}$ & $<1$ & 0.031 & $<1$ & $<1$ \\
Erythromycin & 0.062 & 0.062 & 0.062 & $\mathrm{n} / \mathrm{a}$ \\
Clotrimazole & $\mathrm{n} / \mathrm{a}$ & $\mathrm{n} / \mathrm{a}$ & $\mathrm{n} / \mathrm{a}$ & 0.031 \\
\hline
\end{tabular}

concentrations of $0.25,0.062,0.031,0.01562,0.008$ and $0.002 \mu \mathrm{g} \mathrm{mL}^{-1}$.

From the tested compounds, the most active proved to be $\mathbf{M}-\mathbf{1}$, active against two of three tested strains, followed by the Mannich bases M-2, M-4 and benzimidazole $\mathbf{B}$, active against one of the 3 tested strains. Compound $\mathbf{B}$ exhibited the most significant activity against Pseudomonas aeruginosa (MIC $0.008 \mu \mathrm{g} \mathrm{mL}^{-1}$ ) and $\mathbf{M}-\mathbf{1}$ was found to be twice as active as the standard (MIC $0.031 \mu \mathrm{g} \mathrm{mL}^{-1}$ ). Compound M-4 was two fold active compared to the standard (MIC $0.030 \mu \mathrm{g} \mathrm{mL}{ }^{-1}$ ) and compound M-2 was slightly better than the standard (MIC $0.052 \mu \mathrm{g} \mathrm{mL}^{-1}$ ) against Staphylococcus aureus (MIC $0.062 \mu \mathrm{g} \mathrm{mL}^{-1}$ ). Compound M-1 was also much better than the standard (MIC $0.031 \mu \mathrm{g} \mathrm{mL}^{-1}$ ) against Escherichia coli.

Experimental, a similar behaviour as compared to their microbicidal properties was revealed by the investigation of the anti-biofilm activity of the benzimidazole compounds. (Table 3). Compounds $\mathbf{B}$ and $\mathbf{M}-\mathbf{1}$ were two fold active compared to the standard against Pseudomonas aeruginosa (MBEC $0.01562 \mu \mathrm{g} \mathrm{mL} \mathrm{m}^{-1}$ ) while $\mathbf{M}-\mathbf{5}$ was as active as the standard. Compound M-4 was found to be more active compared to the standard (MBEC 0.031 $\mu \mathrm{g} \mathrm{mL}{ }^{-1}$ ) while $\mathbf{M - 2}$ was eight times less active than the standard (MBEC $0.25 \mu \mathrm{g} \mathrm{mL} \mathrm{mL}^{-1}$ ) against Staphylococcus aureus. Only compound M-1 was active against 
Escherichia coli but eight times less active than the standard (MBEC $0.25 \mu \mathrm{g} \mathrm{mL}^{-1}$ ).

\section{Antifungal activity}

The synthesized compounds B, M-1-M-5 were also screened for in vitro antifungal activity against Candida albicans ATCC 10231 fungal strain. Here, Clotrimazole was used as the standard drug. All the noticed MIC values are listed in the Table 2. Compound $\mathbf{B}$ was 15 times more active than the standard (MIC $0.002 \mu \mathrm{g} \mathrm{mL}{ }^{-1}$ ), while M-1, M-2 and M-4 were almost as active as the standard (MIC $0.031 \mu \mathrm{g} \mathrm{mL}^{-1}$ ) and $\mathbf{M}-3$ was almost half active against the standard (MIC $0.052 \mu \mathrm{g} \mathrm{mL} \mathrm{mL}^{-1}$ ). A slightly different behavior was determined for anti-biofilm activity. Compounds B, M-2 and M-4 were almost as active as the standard (MIC $0.031 \mu \mathrm{g} \mathrm{mL}^{-1}$ ) and compound $\mathbf{M}-\mathbf{1}$ was almost eight times less active than standard.

A better antifungal activity than the antimicrobial activity is indicated for the synthesized compounds, from the MIC and MBEC values.

\section{Symmetry group, molecular size and total energy of the compounds}

Density functional theory at M11/ktzvp level of theory was used to optimize geometries of the Mannich benzimidazole compounds (Fig. 3). For each benzimidazole compound the symmetry group was attributed,

Table 4 The symmetry group, length of molecule and total energy of the benzimidazoles

\begin{tabular}{llcc}
\hline Compound & Symmetry & Length $(\AA)$ & $\mathbf{E}_{\text {tot }}(\mathrm{Ha})$ \\
\hline B & C1 & 8.935 & -533.628 \\
M-1 & C1 & 11.139 & -878.897 \\
M-2 & C1 & 10.823 & -610.780 \\
M-3 & C1 & 12.233 & -1090.231 \\
M-4 & C1 & 13.117 & -1063.781 \\
M-5 & C1 & 13.362 & -1047.842 \\
\hline
\end{tabular}

the length of molecule and total energy were calculated (Table 4). The smallest molecule (8.935 $\AA$ ) with the highest total energy $(-533.628 \mathrm{Ha})$, benzimidazole $\mathbf{B}$, is one of the most reactive compounds considering its antimicrobial activity. The high stability of a molecule, expressed by a small total energy, of $-1090,231 \mathrm{Ha}$, in the case of compound $\mathbf{M - 3}$, is materialized by its low interaction, that is, by a weak antimicrobial activity.

\section{HOMO-LUMO analysis}

Important data on electronic structure are obtained studying the molecular orbitals [73]. The highest occupied molecular orbital $\left(\mathrm{E}_{\mathrm{HOMO}}\right)$ and lowest unoccupied molecular orbital $\left(\mathrm{E}_{\mathrm{LUMO}}\right)$ energy values were determined using DFT at M11/ktzvp level of theory (Table 5) HOMO and LUMO plots of the benzimidazole compounds can be seen in Fig. 5 The HOMO orbital acts as donating electron, and LUMO orbital acts as electron acceptor [76].

The charge density distribution on the HOMO level is localized on benzimidazole ring in the compounds $\mathbf{B}$, M-1 and M-2, meaning on $\mathrm{C}=\mathrm{C}, \mathrm{C}-\mathrm{N}$ and $\mathrm{C}=\mathrm{N}$ bonds, also on the $\mathrm{CH}$ (bonded to $\mathrm{OH}$ ) and oxygen atom; while for the compounds M-3, M-4 and M-5, HOMO is localized on the aromatic ring from the amine, on the two phenyl rings, 4-nitroaniline and 4-aminobenzoic acid residues, respectively, nitro and amino groups, nitrogen from amine $(\mathrm{N}$ or $\mathrm{NH})$ and also on methylene group (Fig. 4).Charge density on LUMO levels indicates electron density transfer from the amine moiety to benzimidazole ring, to the $\mathrm{C}-\mathrm{C}$ and $\mathrm{C}-\mathrm{N}$ bonds. This shifting is very restricted (LUMO plots on benzimidazole are small on $\mathbf{M}-\mathbf{3}$ and $\mathbf{M}-5)$ because of the two phenyl groups in M-3 and $\mathrm{COOH}$ group in $\mathbf{M - 5}$ with tendency to withdraw electron, a negative inductive effect and will permit a low density charge on benzimidazole ring. In compound M-4 seems that the charge shifting on benzimidazole ring is not felt at all because of the both inductive and electromer electron attracting effects of the $\mathrm{NO}_{2}$ group. This difference in charge distribution will also be reflected in their reactivity.

Table 5 Chemical reactivity indices of the compounds M-1-M-5 and B

\begin{tabular}{|c|c|c|c|c|c|c|}
\hline \multirow[t]{2}{*}{ Energy (Hartree) } & \multicolumn{5}{|c|}{ Mannich bases } & \multirow{2}{*}{$\begin{array}{l}\text { BIM } \\
\text { B }\end{array}$} \\
\hline & M-1 & $M-2$ & $M-3$ & $M-4$ & $M-5$ & \\
\hline $\mathrm{E}_{\text {HOMO }}$ & -0.324 & -0.324 & -0.309 & -0.324 & -0.317 & -0.322 \\
\hline $\mathrm{E}_{\text {LUMO }}$ & 0.045 & 0.043 & 0.037 & -0.007 & 0.026 & 0.048 \\
\hline$E_{\text {gap }}$ & -0.369 & -0.367 & -0.346 & -0.317 & -0.343 & -0.370 \\
\hline$\eta$ & $\underline{0.1845}$ & $\underline{0.183}$ & 0.173 & 0.1585 & 0.1715 & $\underline{0.185}$ \\
\hline$\mu$ & -0.1395 & -0.140 & -0.136 & -0.1655 & -0.1455 & -0.137 \\
\hline$\omega$ & $\underline{0.0527}$ & $\underline{0.0535}$ & 0.1069 & $\underline{0.0864}$ & $\underline{0.0617}$ & $\underline{0.050}$ \\
\hline
\end{tabular}




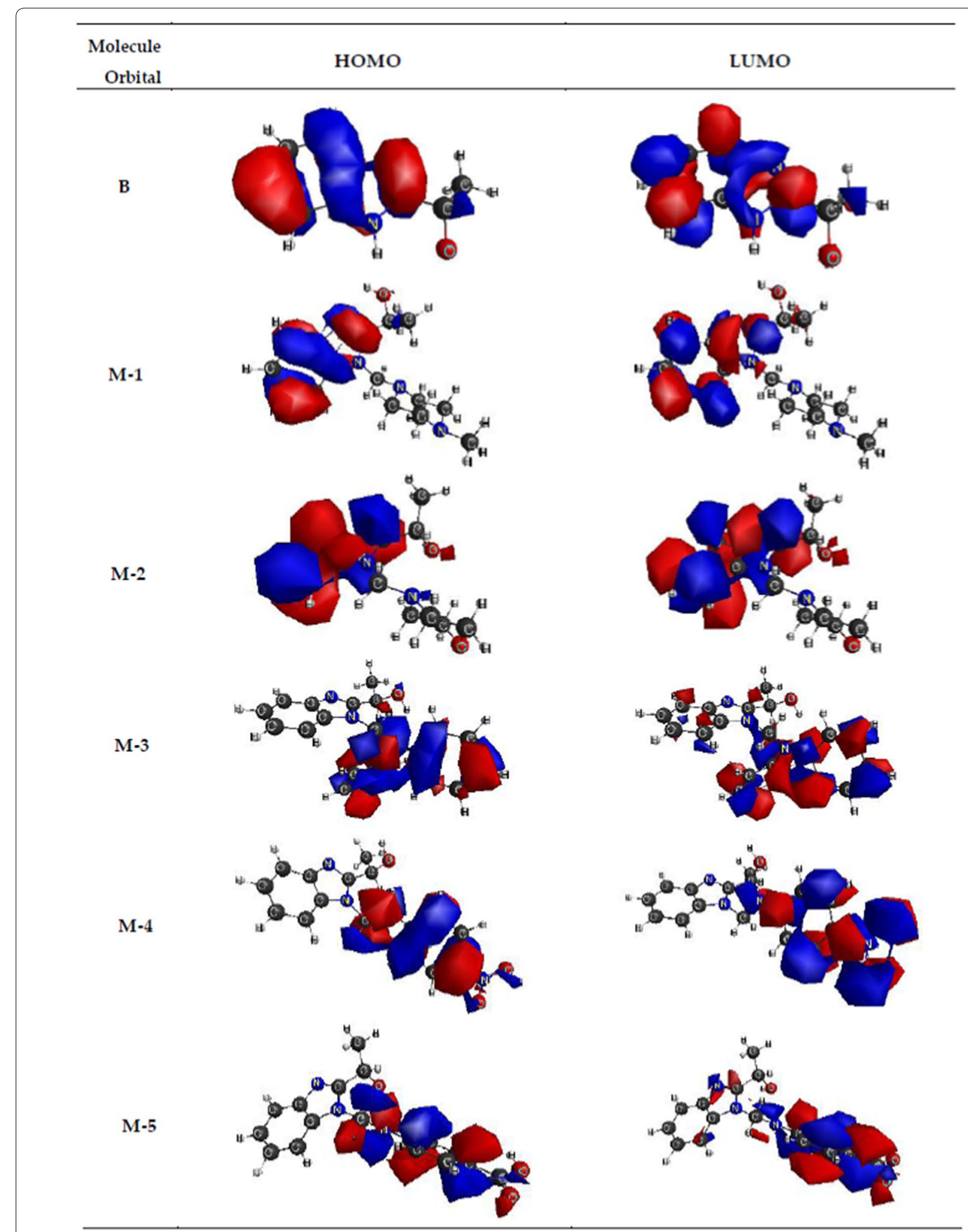

Fig. 4 The HOMO-LUMO plots of the benzimidazole compounds $\mathbf{M}-\mathbf{1}-\mathbf{M}-\mathbf{5}$ and $\mathbf{B}$ 
The energetic values of the HOMO-LUMO levels are at about the same value $-0.324-322 \mathrm{Ha}$ and $0.43-0.48$ Ha respectively, in the gas phase, for the four compounds B, M-1, M-2 and M-4 except for LUMO of M-4 with -0.04 Ha value.

The electronic indices: $\mathrm{E}_{\text {gap }}\left(\mathrm{E}_{\mathrm{HOMO}}-\mathrm{E}_{\mathrm{LUMO}}\right), \eta$ (chemical hardness), $\mu$ (electronic chemical potential), $\omega$ (global electrophilicity index) shown in Table 5 were used to evaluate the chemical reactivity of the benzimidazole compounds.

\section{Electronic parameters of the benzimidazole compounds} A low HOMO-LUMO gap is reflected in a molecule very reactive and less stable. $E_{\text {gap }}$ is the lowest for Mannich base $\mathbf{M - 4}$, which possessed a good antimicrobial activity, on $50 \%$ of all strains tested, for both MIC and MBEC values, but not the best activity of all compounds. A high HOMO-LUMO energy difference is noted for the compound $\mathbf{M - 1}$, that has the best antimicrobial activity, and also resembling values for the compounds $\mathbf{B}$ and

M-2. Shortly, we expect the decreasing activity in the order $\mathbf{M}-\mathbf{4}>\mathbf{M}-\mathbf{5}>\mathbf{M}-\mathbf{3}>\mathbf{M}-\mathbf{2}>\mathbf{M}-\mathbf{1}>\mathbf{B}$, but the order is almost totally inverted. Therefore we must consider the contribution of other parameters to biological activity.

Pearson states the best values of the calculated parameters are obtained in case of the minimum HOMO energy values and maximum energy values of LUMO orbitals [77]. That means for compounds $\mathbf{M - 1}, \mathbf{M}-\mathbf{2}$ and $\mathbf{B}$, the values of $\mathrm{E}_{\text {gap }}$ are best fitted with their reactivity and confirm the antimicrobial behaviour of the tested compounds. Moreover, considering HOMO-LUMO energies values, the decreasing order of the biological activity results as follows: $\mathbf{M}-\mathbf{1}>\mathbf{M}-\mathbf{2}>\mathbf{B}>\mathbf{M}-\mathbf{4}>\mathbf{M}-\mathbf{3}>$ M-5, order that corresponds for the minimum inhibitory concentration variation of the compounds.

Pearson mention that in nature molecules arranges themselves to be as hard as possible [77], so the specific parameter hardness $\eta$, defined as below, has to be larger, in order to have a molecule biologically reactive. Considering the calculated values of hardness (Table 5), a higher biological activity is expected for compounds $\mathbf{B}$, M-1, M-2 and a lower biological activity for M-3, M-4 and M-5. In this case, the following order of decreasing biological activity would result $\mathbf{B}>\mathbf{M}-\mathbf{1}>\mathbf{M}-\mathbf{2}>\mathbf{M}-\mathbf{3}>\mathbf{M}-$ $5>$ M-4. The Minimum Inhibitory Concentration (MIC) values (Table 2) and the minimum biofilm eradication concentration (MBEC) values (Table 3) show biological activities show biological activities lower than expected for compounds $\mathbf{M}-\mathbf{3}, \mathbf{B}$ and $\mathbf{M}-\mathbf{5}$, and higher than expected for $\mathbf{M}-\mathbf{4}$, because the $\eta$ values for $\mathbf{M}-\mathbf{5}, \mathbf{M}-\mathbf{3}$ and $\mathbf{B}$ of $0.1715,0.173$ and 0.185 , respectively, are higher than the $\eta$ value for $\mathbf{M}-\mathbf{4}$ of 0.1585 . The better biological activity of M-4 is related with another parameter, like the charge on atom.

$$
\eta=\frac{E_{L U M O}-E_{H O M O}}{2}
$$

The electronic chemical potential $(\mu)$ defines the reactivity of one compound, so a greater value indicates a more reactive compound. So, we will expect the order of decreasing reactivity: $\mathbf{M}-\mathbf{3}>\mathbf{B}>\mathbf{M}-\mathbf{1}>\mathbf{M}-\mathbf{2}>\mathbf{M}-\mathbf{5}>$ M-4. In this case, a higher activity appears for Mannich base $\mathbf{M - 3}$, and a lower activity for $\mathbf{M - 4}$, values that will be explained by the following discussions.

$$
\mu=\frac{E_{H O M O}+E_{L U M O}}{2}
$$

The last parameter, the global electrophilicity index $(\omega)$, which assesses the electrophilic nature of one molecule in a relative scale, is best correlated with the biological activities of the benzimidazole compounds, as it was formulated in a previous study [6]. Increasing the global electrophilicity indice is consistent with the decrease in biological activity in the order $\mathbf{M}-\mathbf{1}>\mathbf{B}>\mathbf{M}-\mathbf{2}>\mathbf{M}-\mathbf{5}>\mathbf{M}$ -4 $>$ M-3. In this case M-1 appears to be the most biologically active and $\mathbf{M}-\mathbf{3}$ as the least active, which corresponds to the obtained experimental results.

$$
\omega=\frac{\mu^{2}}{2 \eta}
$$

\section{Selected geometrical parameters of the benzimidazole compounds Bond lengths}

Table 6 shows the bond length values of the title benzimidazoles and Fig. 5 indicates the atom numbering in the studied compounds. The resembling values of the bond lengths for the $\mathbf{M - 1}, \mathbf{M}-\mathbf{2}$ and $\mathbf{B}$ in relation with the same counterparts of the molecules and the same localization of the HOMO-LUMO orbitals may explain the three alike biological activities. Shortening the chemical bond $\mathrm{N}^{15}-\mathrm{C}^{16}$ and enlargement the chemical bond $\mathrm{C}^{14}-\mathrm{N}^{15}$ together with the presence of the frontier orbitals on these atoms could explain the low reactivity of the base M-3. The difference between the reactivity of the compounds M-4 and M-5 seems to be better related to the charges on the atoms than to the bond lengths that are very similar.

\section{Bond and dihedral angles}

Determination of bond and dihedral angles is very important for the biological activities of the molecules because a molecule with a flat geometry or a symmetric one possess a better antimicrobial activity than a molecule with 
Table 6 Bond length values of the discussed benzimidazoles

\begin{tabular}{|c|c|c|c|c|c|c|}
\hline \multirow[t]{2}{*}{ Chemical bond } & \multicolumn{6}{|c|}{ Length $(\AA ̊)$} \\
\hline & M-1 & $M-2$ & $M-3$ & $M-4$ & $M-5$ & $1 \mathrm{~B}$ \\
\hline$C^{8}-C^{10}$ & 1.506 & 1.509 & 1.511 & 1.506 & 1.505 & 1.507 \\
\hline$C^{10}-C^{12}$ & 1.528 & 1.520 & 1.517 & 1.517 & 1.517 & 1.518 \\
\hline $\mathrm{C}^{10}-\mathrm{O}^{11}$ & 1.415 & 1.430 & 1.426 & 1.438 & 1.438 & 1.427 \\
\hline $\mathrm{O}^{11}-\mathrm{H}^{20}$ & 0.966 & 0.963 & 0.961 & 0.963 & 0.963 & 0.961 \\
\hline$N^{7}-C^{14}$ & 1.445 & 1.453 & 1.447 & 1.442 & 1.443 & - \\
\hline$C^{14}-N^{15}$ & 1.446 & 1.441 & 1.458 & 1.446 & 1.445 & - \\
\hline$N^{15}-C^{16}$ & 1.458 & 1.460 & 1.429 & 1.370 & 1.374 & - \\
\hline$C^{16}-C^{17}$ & 1.519 & 1.519 & 1.397 & 1.407 & 1.404 & - \\
\hline$C^{17}-X^{18}$ & 1.454 & 1.421 & 1.385 & 1.373 & 1.367 & - \\
\hline$X^{18}-C^{19}$ & 1.451 & - & 1.387 & 1.388 & 1.396 & - \\
\hline$C^{19}-Y^{20}$ & - & - & 1.386 & 1.467 & 1.493 & - \\
\hline $\mathrm{N}^{21}-\mathrm{O}^{22}\left(\mathrm{NO}_{2}\right)$ & - & - & - & 1.213 & - & - \\
\hline $\mathrm{C}-\mathrm{O}(\mathrm{COOH})$ & - & - & - & - & 1.354 & - \\
\hline $\mathrm{C}=\mathrm{O}(\mathrm{COOH})$ & & - & - & - & 1.196 & - \\
\hline $\mathrm{OH}(\mathrm{COOH})$ & & - & - & - & 0.961 & - \\
\hline
\end{tabular}

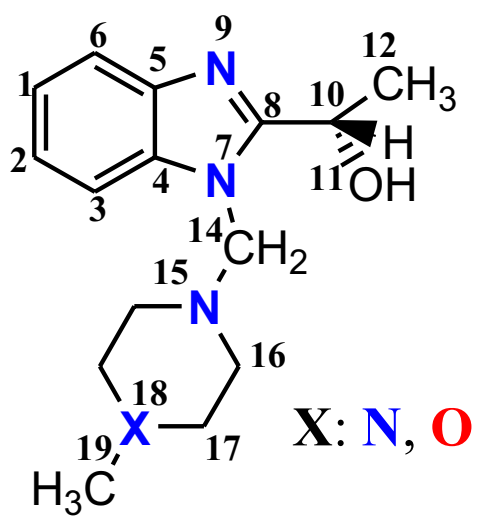

B, M-1, M-2

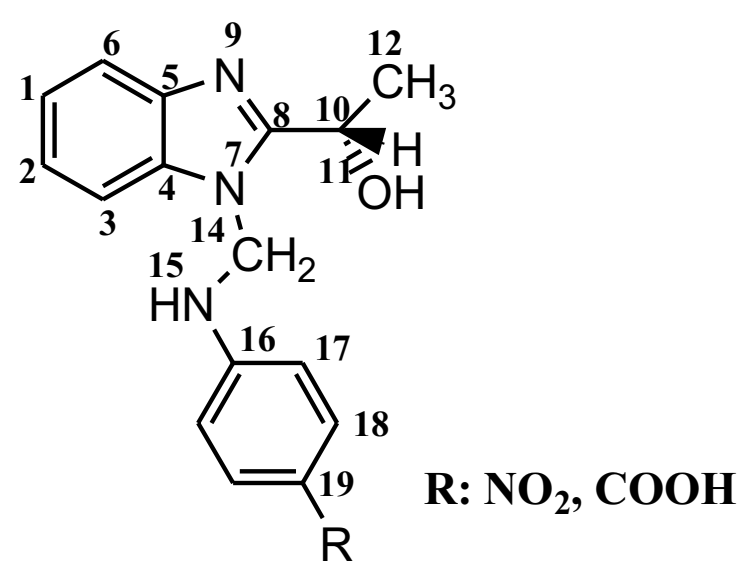

M-3-M-5

Fig. 5 Numbering of the atoms on the studied compounds

a distorted geometry $[6,22]$. Moreover, the presence of a charge of a heteroatom on a molecule is an advantage for the biological activity. By analyzing the bond and dihedral angles from Table 7, we may conclude: Mannich base M-1 is composed of two moieties, each of them almost planar, the benzimidazole and 1-methylpiperazine, situated at 111.508 degrees $\left(\mathrm{N}^{7} \mathrm{C}^{14} \mathrm{~N}^{15}\right)$. The negative charge on the methyl group $(-0.383)$ seems to increase the biological activity of the compound. Compound $\mathbf{M - 2}$ possessed similar geometry to $\mathbf{M}-\mathbf{1}$, slightly sharper, but lack of the methyl group leads to a decrease in biological activity, even if the charge of oxygen atom $(-0.301)$ is present on the aliphatic heterocycle. The perfectly planar geometry of the benzimidazole $\mathbf{B}$ is reflected in its good reactivity, similar with compound $\mathbf{M}-\mathbf{2}$.

The compound $\mathbf{M}-\mathbf{3}$ has a very twisted geometry, three very sharp dihedral angles: $21.463\left(\mathrm{~N}^{9} \mathrm{C}^{8} \mathrm{C}^{10} \mathrm{C}^{12}\right)$, $-22.117\left(\mathrm{C}^{14} \mathrm{~N}^{15} \mathrm{C}^{16} \mathrm{C}^{17}\right)$ and $-20.795\left(\mathrm{C}^{17} \mathrm{C}^{16} \mathrm{~N}^{15} \mathrm{C}^{21}\right)$, resulting in a drastic decrease in antimicrobial activity. The geometries of $\mathbf{M - 4}$ and $\mathbf{M}-\mathbf{5}$ are somewhat similar. Compound $\mathbf{M}-\mathbf{4}$ is composed of two planar moieties, which greatly contribute to the increase of 
Table 7 Bond and dihedral angles of the benzimidazole compounds

\begin{tabular}{|c|c|c|c|c|c|c|}
\hline \multirow[t]{2}{*}{ Parameter } & \multicolumn{6}{|c|}{ Angle value } \\
\hline & $M-1$ & $M-2$ & $M-3$ & $M-4$ & $M-5$ & 1B \\
\hline$C^{8} C^{10} C^{12}$ & 109.668 & 110.798 & 110.682 & 111.723 & 111.686 & 110.467 \\
\hline $\mathrm{C}^{8} \mathrm{C}^{10} \mathrm{O}^{11}$ & 108.911 & 108.962 & 111.489 & 108.316 & 108.338 & 109.028 \\
\hline$N^{7} C^{14} N^{15}$ & 111.508 & 111.566 & 112.662 & 110.528 & 110.507 & 112.093 \\
\hline$N^{7} C^{8} C^{10} C^{12}$ & -95.951 & -150.864 & -161.515 & 157.901 & -157.392 & 77.533 \\
\hline$N^{9} C^{8} C^{10} C^{12}$ & 81.831 & 34.525 & $\underline{21.463}$ & -29.587 & 30.127 & 99.982 \\
\hline$N^{7} C^{8} C^{10} O^{11}$ & 142.003 & 86.402 & -40.111 & -29.587 & 79.257 & 161.069 \\
\hline$N^{7} C^{14} N^{15} C^{16}$ & -173.275 & 111.566 & -50.042 & -178.827 & 177.665 & - \\
\hline$C^{14} N^{15} C^{16} C^{17}$ & 177.597 & 177.202 & -22.117 & 168.667 & -168.389 & - \\
\hline$C^{16} C^{17} N^{18} C^{19}$ & 177.057 & - & - & - & - & - \\
\hline$C^{17} C^{16} N^{15} C^{21}$ & - & & -20.795 & - & - & \\
\hline $\mathrm{C}^{18} \mathrm{C}^{19} \mathrm{NO}$ & - & - & - & -179.820 & - & - \\
\hline $\mathrm{C}^{18} \mathrm{C}^{19} \mathrm{CO}$ & - & - & - & - & $\underline{20.368}$ & - \\
\hline
\end{tabular}

antimicrobial activity, while the 4-aminobenzoic acid residue has a 20.368 (dihedral angle $\mathrm{C}^{18} \mathrm{C}^{19} \mathrm{CO}$ ) degree deviation from the planarity, which leads to a large decrease in biological activity.
Mulliken atomic charges

Table 8 presents the Mulliken atomic charges calculated using DFT at M11/ktzvp level of theory. Previous studies showed that an increased charge favors a good

Table 8 Mulliken atomic charges of compounds M-1-M-5 and B

\begin{tabular}{|c|c|c|c|c|c|c|}
\hline \multirow[t]{2}{*}{ Atom } & \multicolumn{6}{|c|}{ Mulliken charge } \\
\hline & $M-1$ & M-2 & $M-3$ & $M-4$ & $M-5$ & $\mathrm{~B}^{\mathrm{a}}$ \\
\hline C-1 (Benzimidazole) & -0.149 & -0.150 & -0.135 & -0.132 & -0.132 & -0.132 \\
\hline C-2 (Benzimidazole) & -0.182 & -0.182 & -0.168 & -0.192 & -0.198 & -0.189 \\
\hline C-3 (Benzimidazole) & -0.058 & -0.057 & -0.105 & -0.057 & -0.056 & -0.089 \\
\hline C-4 (Benzimidazole) & -0.042 & -0.037 & -0.067 & -0.041 & -0.042 & 0.013 \\
\hline C-5(Benzimidazole) & 0.009 & 0.012 & 0.028 & 0.022 & 0.023 & 0.010 \\
\hline C-6 (Benzimidazole) & -0.113 & -0.122 & -0.136 & -0.129 & -0.130 & -0.143 \\
\hline N-7 (Benzimidazole) & -0.296 & -0.321 & -0.301 & -0.349 & -0.347 & -0.389 \\
\hline C-8 (Benzimidazole) & 0.194 & -0.186 & 0.321 & 0.249 & 0.247 & 0.167 \\
\hline N-9 (Benzimidazole) & -0.386 & -0.317 & -0.320 & -0.315 & -0.316 & -0.312 \\
\hline$C-10$ & -0.016 & -0.028 & -0.149 & -0.196 & -0.195 & -0.020 \\
\hline O-11 & -0.432 & -0.443 & -0.447 & -0.451 & -0.450 & -0.435 \\
\hline$C-12$ & -0.408 & -0.466 & -0.471 & -0.467 & -0.466 & -0.349 \\
\hline$C-14$ & -0.319 & -0.186 & -0.251 & -0.136 & -0.140 & - \\
\hline$N-15$ & -0.241 & -0.323 & -0.527 & -0.488 & -0.491 & - \\
\hline$C-16$ & -0.262 & -0.230 & -0.178 & 0.253 & 0.256 & - \\
\hline$C-17$ & -0.350 & -0.215 & -0.106 & -0.225 & -0.280 & - \\
\hline$X-18$ & $-0.255(\mathrm{~N})$ & $-0.301(\mathrm{O})$ & -0.172 & -0.099 & -0.027 & - \\
\hline $\mathrm{C}-19\left(\mathrm{CH}_{3}\right)$ & -0.383 & - & -0.128 & -0.143 & -0.441 & - \\
\hline $\mathrm{N}-20\left(\right.$ from $\left.\mathrm{NO}_{2}\right)$ & - & - & - & 0.317 & - & - \\
\hline $\mathrm{O}-21$ (from NO $2, \mathrm{COOH}$ ) & - & - & - & -0.288 & -0.384 & - \\
\hline $\mathrm{O}-22$ (from $\mathrm{NO}_{2}, \mathrm{COOH}$ ) & - & - & - & -0.286 & -0.345 & - \\
\hline $\mathrm{C}-20($ from $\mathrm{COOH})$ & - & - & - & - & $\underline{0.502}$ & - \\
\hline $\mathrm{H}-22$ (from $\mathrm{COOH}$ ) & - & - & - & - & 0.306 & - \\
\hline
\end{tabular}

a From Ref. [6] 
biological activity [6]. It can be said this observation is valid for $\mathbf{M - 1}, \mathbf{M}-\mathbf{2}$ and $\mathbf{M - 4}$ bases due to the two charges localized on the following atoms: on nitrogen $(\mathrm{N}-18)$ of -0.255 , on oxygen $(\mathrm{O}-18)$ of -0.301 , and on nitrogen (from $\mathrm{NO}_{2}$ ) of 0.317 , and also for $\mathbf{B}$ because of the charge on $\mathrm{O}-11$ of -0.435 .

Only a high charge on the O-11 atom is not sufficient for good antimicrobial activity, as shown in Table 8 . It seems that a too high charge on the amine nitrogen (N-15) leads to a decrease in biological activity, as can be seen for bases M-3 and M-5 with charges of -0.527 and -0.491 , respectively. The high atomic charge on some carbon atoms (C-12, C-14, C-16, C-17, $\mathrm{C}-19)$ is explained by the neighborhood of one or more electronegative elements and the rearrangement of the charge. In this case, the negative charge on the carbon can be considered as a formal charge.

It is obvious that the $\mathbf{B}$ and $\mathbf{M}-\mathbf{1}$ molecules stand out, with an antimicrobial activity superior to the other compounds due to their structural characteristics, which constitute advantages for the structure-activity relationship, among which we can mention:

- small size of molecules, with a length of $8935 \AA$ and 11,139 A respectively;

- almost identical HOMO-LUMO energy difference of the two compounds $(-0.370$ and $-0.369 \mathrm{Ha}$ respectively);

- global electrophilicity indices have the lowest values of all ( 0.050 and 0.0527 respectively);

- the almost flat structure of the two molecules, which results from the values of the angles presented in Table 6, constitutes a major advantage over the other molecules that have a three-dimensional and even distorted structure in some cases (M-3);

- a minimum Mulliken charge on oxygen atom (from $\mathrm{OH}$ group), which means a higher hydrophobicity, is materialized by an increase in antimicrobial activity;

- the presence of the two nitrogen heteroatoms in the piperazine heterocycle, as well as the methyl group linked to the nitrogen atom, favors a higher total Mulliken charge, fact materialized by better biological properties than the other homologous Mannich bases;

- the majority localization of HOMO and LUMO orbitals on the benzimidazole heterocycle in molecules $\mathbf{B}$ and $\mathbf{M}-\mathbf{1}$, as well as the very close energy values of these orbitals (Table 4), are advantages that lead to a better antimicrobial activity.

\section{Experimental section}

Elemental analysis was performed with a "multi EA 4000" device from "Analytik Jena". Fourier transform infrared (FTIR) spectra have been acquired by using a "Vertex 70-Bruker" spectrophotometer, in $\mathrm{KBr}$ pellets. The NMR spectra were recorded on Bruker Advance Ultrashield Plus spectrometer operating at $300.18 \mathrm{MHz}$ for ${ }^{1} \mathrm{H}$ and $125 \mathrm{MHz}$ for ${ }^{13} \mathrm{C}$. The enantiomeric ratios were determined by HPLC analysis with a CHIRALPAK AS column $(4.6 \times 250 \mathrm{~mm}),[254 \mathrm{~nm}, 0.50 \mathrm{~mL} /$ minute, i-propanolhexane (90:10)]. Optical rotations were recorded on a Perkin-Elmer 236 polarimeter and the $[\alpha]_{D}$ values are given in units of $10^{-1} \mathrm{deg} \mathrm{cm}^{2} \mathrm{~g}^{-1}$. Melting points were determined in open capillary tubes using a STUART SMP3 electric melting point apparatus and are uncorrected. $M+1$ peaks were determined on an Agilent 1100 series and an Agilent Ion Trap SL mass spectrometer (Santa Clara, CA, USA), operating at $70 \mathrm{eV}$.

\section{Synthesis of (S)-1-(1H-Benzo[d]imidazole-2-yl)ethanol (B)}

A mixture of (S)-2-hydroxypropanoic acid (50 mmol), $o$-phenylenediamine $(50 \mathrm{mmol})$ and $4 \mathrm{~N}$ hydrochloric acid, thoroughly grounded with a pestle in a mortar at room temperature until liquefied, was subsequently heated at $140{ }^{\circ} \mathrm{C}$ for $2 \mathrm{~h}$. The progress of the reaction was monitored by thin-layer chromatography (TLC). After cooling, the resulting mass was washed with ammonia, filtered, and the final product was recrystallized from ethanol. Colourless solid. Yield $80 \%$ (3.64 g) m.p. 177$178^{\circ} \mathrm{C}$; similar to [29] (m.p. $\left.176-178^{\circ} \mathrm{C}\right) . \mathrm{IR}\left(\mathrm{cm}^{-1}, \mathrm{KBr}\right)$ : 3356 (aromatic - NH bending), 3364 (OH stretching), 3070 (aromatic $\mathrm{C}-\mathrm{H}$ stretching), 1505 (C-N stretching), 1458 ( $-\mathrm{C}=\mathrm{C}$ stretching), $1315\left(-\mathrm{C}-\mathrm{N}\right.$ stretching); ${ }^{1} \mathrm{H}-$ NMR, $\left(300 \mathrm{MHz}, \mathrm{DMSO}-d_{6}\right): \delta=12.23(\mathrm{~s}, 1 \mathrm{H}, \mathrm{N} H), 7.54$ $\left(\mathrm{d}, \mathrm{H}-6,{ }^{3} \mathrm{~J}=8.6 \mathrm{~Hz}\right), 7.44\left(\mathrm{~d}, \mathrm{H}-3,{ }^{3} \mathrm{~J}=8.6 \mathrm{~Hz}\right), 7.12(\mathrm{~d}, 2 \mathrm{H}$, $\left.\mathrm{H}-1,2,{ }^{3} \mathrm{~J}=5.7 \mathrm{~Hz}\right), 5.77\left(\mathrm{t}, 1 \mathrm{H}, \mathrm{OH},{ }^{3} \mathrm{~J}=4.5 \mathrm{~Hz}\right), 4.94(\mathrm{q}$, $\left.1 \mathrm{H}, \mathrm{CH},{ }^{3} \mathrm{~J}=6.5 \mathrm{~Hz}\right), 1.51\left(\mathrm{~d}, 3 \mathrm{H}, \mathrm{CH}_{3},{ }^{3} \mathrm{~J}=6.6 \mathrm{~Hz}\right) \mathrm{ppm}$. ${ }^{13} \mathrm{C}-\mathrm{NMR},\left(125 \mathrm{MHz}, \mathrm{DMSO}-d_{6}\right): \delta=158.6(\mathrm{C}-8), 143.1$ (C-4), 134.1 (C-5), 121.6 and 120.9 (C-1 and C-2), 118.4 (C-3), $111.3(\mathrm{C}-6), 63.7(\mathrm{CH}), 22.9\left(\mathrm{CH}_{3}\right)$ ppm. Elemental analysis (\%) found for $\mathrm{C}_{9} \mathrm{H}_{10} \mathrm{~N}_{2} \mathrm{O}: \mathrm{C}, 66.57 ; \mathrm{H}, 6.25$; $\mathrm{N}, 17.29 ; \mathrm{O}, 9.89$. calcd.: $\mathrm{C}, 66.65 ; \mathrm{H}, 6.21 ; \mathrm{N}, 17.27 ; \mathrm{O}$, 9.86\%. MS (ESI, $70 \mathrm{eV}$ ): m/z calc. for $\mathrm{C}_{9} \mathrm{H}_{10} \mathrm{~N}_{2} \mathrm{O}[\mathrm{M}+\mathrm{H}]^{+}$: 163.19 , found 163.18 .

\section{Synthesis of the Mannich bases M-1-M-5}

A mixture of (S)-1-(1H-benzo[d]imidazole-2-yl)ethanol (B) $(10 \mathrm{mmol})$, formaldehyde $(10 \mathrm{mmol})$, the corresponding amine (1-methylpiperazine, morpholine, diphenylamine, 4-nitroaniline, 4-amino benzoic acid) (10 mmol) and 4-5 drops of concentrated hydrochloric acid in ethanol was stirred at room temperature for 
$2 \mathrm{~h}$ and then refluxed for additional $3 \mathrm{~h}$. After cooling, Mannich bases were filtered under suction, dried, and recrystallized from dimethylformamide (DMF).

(S)-1-(1-((4-Methylpiperazin-1-yl)methyl)-1H-benzo[d] imidazole-2-yl)ethanol (M-1) White solid. Yield 73\% (2 g). m.p. $153-154{ }^{\circ} \mathrm{C} . R_{f}=0.72$ (silica, EtOAc). IR $\left(\mathrm{cm}^{-1}, \mathrm{KBr}\right)$ : 3350 (OH stretching), 2977, 2939 (CH arene stretching), 1459 ( $\mathrm{CH}_{2}$ bending), 1384 ( $\mathrm{C}-\mathrm{N}$ stretching), 1370 (aromatic tertiary amine), 1162 (C-N stretching tertiary amine), 819 (out-of-plane $\mathrm{CH}$ bending), 745 (o-phenylene). ${ }^{1} \mathrm{H}-\mathrm{NMR},\left(300 \mathrm{MHz}, \mathrm{DMSO}-d_{6}\right): \delta=7.62(\mathrm{~d}, 2 \mathrm{H}$, $\mathrm{H}-3,6,{ }^{3} \mathrm{~J}=8.6 \mathrm{~Hz}$ ), 7.19 (d, 2H, H-1,2, ${ }^{3} \mathrm{~J}=5.7 \mathrm{~Hz}$ ), 5.79 (brs, $1 \mathrm{H}, \mathrm{OH}), 5.10\left(\mathrm{dd}, 2 \mathrm{H}, \mathrm{CH}_{2},{ }^{3} \mathrm{~J}=6.5 \mathrm{~Hz}\right) 4.94(\mathrm{q}, 1 \mathrm{H}$, $\mathrm{CH},{ }^{3} \mathrm{~J}=6.5 \mathrm{~Hz}$ ), $2.5\left(\mathrm{~d}, 8 \mathrm{H}, 4 \mathrm{CH}_{2},{ }^{3} \mathrm{~J}=6.5 \mathrm{~Hz}\right), 2.12(\mathrm{~d}$, $\left.3 \mathrm{H}, \mathrm{CH}_{3},{ }^{3} \mathrm{~J}=6.7 \mathrm{~Hz}\right), 1.50\left(\mathrm{~d}, 3 \mathrm{H}, \mathrm{CH}_{3},{ }^{3} \mathrm{~J}=6.6 \mathrm{~Hz}\right) \mathrm{ppm}$. ${ }^{13} \mathrm{C}-\mathrm{NMR},\left(125 \mathrm{MHz}, \mathrm{DMSO}-d_{6}\right): \delta=157.12,141.40$, 136.12, 122.37, 121.52, 119.10, 110.73, 64.04, 61.40, 54.34, 49.80, 45.63, $21.05 \mathrm{ppm}$. Elemental analysis (\%) found for $\mathrm{C}_{15} \mathrm{H}_{22} \mathrm{~N}_{4} \mathrm{O}: \mathrm{C}, 65.59 ; \mathrm{H}, 8.13 ; \mathrm{N}, 20.47 ; \mathrm{O}, 5.71$. calcd.: $\mathrm{C}$, 65.66; H, 8.08; N, 20.42; O, 5.83\%. MS (ESI, $70 \mathrm{eV}): \mathrm{m} / \mathrm{z}$ calc. for $\mathrm{C}_{15} \mathrm{H}_{22} \mathrm{~N}_{4} \mathrm{O}[\mathrm{M}+\mathrm{H}]^{+}$: 275.37, found 275.39.

(S)-1-(1-((4-Morpholin-1-yl)methyl)-1H-benzo[d]imidazole-2-yl)ethanol (M-2) White solid. Yield 75\% (1.95 g). m.p. $137-138{ }^{\circ} \mathrm{C} . R_{f}=0.56$ (silica, EtOAc). IR $\left(\mathrm{cm}^{-1}\right.$, $\mathrm{KBr})$ : 3350 ((OH stretching), 3056 ( $\mathrm{CH}$ arene stretching), 1457 ( $\mathrm{CH}_{2}$ bending), 1317, 1308, 1272 (C-N stretching), 1105 (C-O-C cyclic ether stretching), 808 (out-of-plane $\mathrm{CH}$ bending), 742 (o-phenylene). ${ }^{1} \mathrm{H}-\mathrm{NMR},(300 \mathrm{MHz}$, DMSO- $\left.d_{6}\right): \delta=7.62\left(\mathrm{~d}, \mathrm{H}-6,{ }^{3} \mathrm{~J}=8.6 \mathrm{~Hz}\right), 7.48(\mathrm{~s}, \mathrm{H}-3)$, 7.15 (d, 2H, H-1,2, $\left.{ }^{3} \mathrm{~J}=5.7 \mathrm{~Hz}\right), 5.74(\mathrm{~s}, 1 \mathrm{H}, \mathrm{OH}), 5.12$ (dd, $\left.2 \mathrm{H}, \mathrm{CH}_{2},{ }^{3} \mathrm{~J}=6.5 \mathrm{~Hz}\right), 4.96\left(\mathrm{~d}, 1 \mathrm{H}, \mathrm{CH},{ }^{3} \mathrm{~J}=6.5 \mathrm{~Hz}\right.$ ), $3.53\left(\mathrm{~d}, 2 \mathrm{H}, \mathrm{CH}_{2},{ }^{3} \mathrm{~J}=6.5 \mathrm{~Hz}\right), 3.36\left(\mathrm{~d}, 2 \mathrm{H}, \mathrm{CH}_{2}\right.$, $\left.{ }^{3} \mathrm{~J}=6.5 \mathrm{~Hz}\right), 2.50\left(4 \mathrm{H}, 2 \mathrm{CH}_{2},{ }^{3} \mathrm{~J}=6.5 \mathrm{~Hz}\right), 1.51(\mathrm{~d}, 3 \mathrm{H}$, $\left.\mathrm{CH}_{3},{ }^{3} \mathrm{~J}=6.6 \mathrm{~Hz}\right) \mathrm{ppm} .{ }^{13} \mathrm{C}-\mathrm{NMR},\left(125 \mathrm{MHz}\right.$, DMSO- $\left.d_{6}\right)$ : $\delta=157.06,141.44,136.11,122.35,121.54,121.21,119.06$, $110.85,66.16,65.96,63.67,61.45,50.40,22.97$ ppm. Elemental analysis (\%) found for $\mathrm{C}_{14} \mathrm{H}_{19} \mathrm{~N}_{3} \mathrm{O}_{2}$ : C, 64.39; $\mathrm{H}$, 7.27; N, 16.14; O, 5.71. calcd.: C, 64.35; H, 7.32; N, 16.08; O, 12.19\%. MS (ESI, $70 \mathrm{eV}$ ): $\mathrm{m} / \mathrm{z}$ calc. for $\mathrm{C}_{14} \mathrm{H}_{19} \mathrm{~N}_{3} \mathrm{O}_{2}$ $[\mathrm{M}+\mathrm{H}]^{+}:$262.32, found 262.37 .

(S)-1-(1-((Diphenylamino)methyl)-1H-benzo[d]imidazole-2-yl)ethanol (M-3) Light-yellow solid. Yield 81\% $\left(2.78\right.$ g). m.p. $168-169{ }^{\circ} \mathrm{C} . R_{f}=0.54$ (silica, EtOAc). IR $\left(\mathrm{cm}^{-1}, \mathrm{KBr}\right): 3450$ (OH stretching), 3085, $3055(\mathrm{CH}$ arene stretching), 1621 ( $\mathrm{C}=\mathrm{C}$ stretching), $1495\left(\mathrm{CH}_{2}\right.$ bending), 1316, 1308, 1272 (C-N stretching), 1104 (C-C-C bending), 744 (o-phenylene). ${ }^{1} \mathrm{H}-\mathrm{NMR},\left(300 \mathrm{MHz}, \mathrm{DMSO}-d_{6}\right)$ : $\delta=7.74\left(\mathrm{~d}, \mathrm{H}-6,{ }^{3} \mathrm{~J}=8.6 \mathrm{~Hz}\right), 7.53\left(\mathrm{~d}, \mathrm{H}-3,{ }^{3} \mathrm{~J}=8.6 \mathrm{~Hz}\right)$, 7.44 (m, 4H, CH aromatic), 7.09 (m, 6H, CH aromatic), $6.91\left(\mathrm{~d}, 1 \mathrm{H},{ }^{3} \mathrm{~J}=5.7 \mathrm{~Hz}\right), 6.84\left(\mathrm{~d}, 1 \mathrm{H},{ }^{3} \mathrm{~J}=5.7 \mathrm{~Hz}\right), 6.01$ $\left(\mathrm{dd}, 2 \mathrm{H}, \mathrm{CH}_{2},{ }^{3} \mathrm{~J}=6.5 \mathrm{~Hz}\right), 5.74(\mathrm{~s}, 1 \mathrm{H}, \mathrm{OH}), 4.72(\mathrm{~d}, 1 \mathrm{H}$, $\left.\mathrm{CH},{ }^{3} \mathrm{~J}=6.5 \mathrm{~Hz}\right), 1.60\left(\mathrm{~d}, 3 \mathrm{H}, \mathrm{CH}_{3},{ }^{3} \mathrm{~J}=6.6 \mathrm{~Hz}\right) \mathrm{ppm} .{ }^{13} \mathrm{C}-$ NMR, (125 MHz, DMSO- $\left.d_{6}\right): \delta=158.67,147.71,143.47$, $129.18,127.52,126.63,124.64,121.29,121.10,120.40$, 119.68, 117.05, 116.76, 116.46, 81.27, 63.67, 23.05 ppm. Elemental analysis (\%) found for $\mathrm{C}_{22} \mathrm{H}_{21} \mathrm{~N}_{3} \mathrm{O}: \mathrm{C}, 76.99 ; \mathrm{H}$, 6.22; N, 12.08; O, 4.71. calcd.: C, 76.94; H, 6.16; N, 12.23; O, 4.66\%. MS (ESI, $70 \mathrm{eV}$ ): $\mathrm{m} / \mathrm{z}$ calc. for $\mathrm{C}_{22} \mathrm{H}_{21} \mathrm{~N}_{3} \mathrm{O}$ $[\mathrm{M}+\mathrm{H}]^{+}: 343.43$, found 343.35 .

(S)-1-(1-((4-nitrophenylamino)methyl)-1H-benzo[d] imidazole-2-yl)ethanol (M-4) Yellow solid. Yield 83\% (2.78 g). m.p. $193-194{ }^{\circ} \mathrm{C} . R_{f}=0.57$ (silica, EtOAc). IR (cm $\left.{ }^{-1}, \mathrm{KBr}\right): 3469$ (OH stretching), 1603 (NH stretching), 1530 ( $\mathrm{CH}_{2}$ bending), 1498, 1470 (aromatic nitro), 1321, 1299, 1268 (C-N stretching), 1189 (C-N tertiary amine), 1109, 1097 (C-C-C bending), 835 (NH stretching), 753 (o-phenylene).

${ }^{1} \mathrm{H}-\mathrm{NMR}, \quad\left(300 \mathrm{MHz}, \quad\right.$ DMSO- $\left.d_{6}\right): \delta=8.02$ (d, 2H, $\left.{ }^{3} \mathrm{~J}=8.6 \mathrm{~Hz}\right), 7.92(\mathrm{~s}, \mathrm{NH}), 7.63\left(\mathrm{~d}, 1 \mathrm{H},{ }^{3} \mathrm{~J}=5.7 \mathrm{~Hz}\right), 7.46$ $\left(\mathrm{d}, 1 \mathrm{H},{ }^{3} \mathrm{~J}=5.7 \mathrm{~Hz}\right), 7.09\left(\mathrm{~d}, 2 \mathrm{H},{ }^{3} \mathrm{~J}=8.6 \mathrm{~Hz}\right), 6.80(\mathrm{~d}$, $\left.2 \mathrm{H},{ }^{3} \mathrm{~J}=8.6 \mathrm{~Hz}\right), 5.72(\mathrm{~s}, 1 \mathrm{H}, \mathrm{OH}), 5.46\left(\mathrm{~d}, 2 \mathrm{H}, \mathrm{CH}_{2}\right.$, $\left.{ }^{3} \mathrm{~J}=6.5 \mathrm{~Hz}\right), 4.92\left(\mathrm{~d}, 1 \mathrm{H}, \mathrm{CH},{ }^{3} \mathrm{~J}=6.5 \mathrm{~Hz}\right), 1.51(\mathrm{~d}, 3 \mathrm{H}$, $\left.\mathrm{CH}_{3},{ }^{3} \mathrm{~J}=6.6 \mathrm{~Hz}\right)$ ppm. ${ }^{13} \mathrm{C}-\mathrm{NMR},(125 \mathrm{MHz}, \mathrm{DMSO}-$ $\left.d_{6}\right): \delta=158.54,153.23,138.56,136.79,134.38,126.04$, $125.96,125.52,125.27,125.10,121.53,120.84,113.56$, 81.38, 63.39, $22.96 \mathrm{ppm}$. Elemental analysis (\%) found for $\mathrm{C}_{16} \mathrm{H}_{16} \mathrm{~N}_{4} \mathrm{O}_{3}: \mathrm{C}, 61.59 ; \mathrm{H}, 5.22 ; \mathrm{N}, 17.98 ; \mathrm{O}, 15.20$. calcd.: C, 61.53; H, 5.16; N, 17.93; O, 15.37\%. MS (ESI, $70 \mathrm{eV}$ ): $\mathrm{m} / \mathrm{z}$ calc. for $\mathrm{C}_{16} \mathrm{H}_{16} \mathrm{~N}_{4} \mathrm{O}_{3}[\mathrm{M}+\mathrm{H}]^{+}: 313.34$, found 313.38 .

(S)-4-((2-(1-Hydroxyethyl)-1H-benzo[d]imidazol-1-yl) methylamino)benzoic acid (M-5) Yellow solid. Yield $78 \%$ (2.42 g). m.p. $223-224{ }^{\circ} \mathrm{C} . R_{f}=0.49$ (silica, EtOAc). IR (cm $\left.{ }^{-1}, \mathrm{KBr}\right): 3400-3100$ (OH stretching), 2925 (CH arene stretching), 1682 ( $\mathrm{C}=\mathrm{C}$ stretching), 1603 (NH stretching), 1519 ( $\mathrm{CH}_{2}$ bending), 1315, 1241 (C-N stretching), 1175 (C-N tertiary amine), 1084 (C-C-C bending), 841 ( $\mathrm{NH}$ stretching), 745, 699 (o-phenylene). ${ }^{1} \mathrm{H}$-NMR, $\left(300 \mathrm{MHz}\right.$, DMSO- $\left.d_{6}\right): \delta=7.72\left(\mathrm{~d}, 2 \mathrm{H},{ }^{3} \mathrm{~J}=8.6 \mathrm{~Hz}\right)$, $7.61\left(\mathrm{~d}, 2 \mathrm{H},{ }^{3} \mathrm{~J}=5.7 \mathrm{~Hz}\right), 6.88\left(\mathrm{~d}, 2 \mathrm{H},{ }^{3} \mathrm{~J}=8.6 \mathrm{~Hz}\right), 6.71$ $\left(\mathrm{d}, 1 \mathrm{H},{ }^{3} \mathrm{~J}=8.6 \mathrm{~Hz}\right), 6.58\left(\mathrm{~d}, 1 \mathrm{H},{ }^{3} \mathrm{~J}=8.6 \mathrm{~Hz}\right), 5.79(\mathrm{dd}$, $\left.2 \mathrm{H}, \mathrm{CH}_{2},{ }^{3} \mathrm{~J}=6.5 \mathrm{~Hz}\right), 5.34$ (brs, $\left.1 \mathrm{H}, \mathrm{OH}\right), 4.94(\mathrm{q}, 1 \mathrm{H}$, $\left.\mathrm{CH},{ }^{3} \mathrm{~J}=6.5 \mathrm{~Hz}\right), 1.51\left(\mathrm{~d}, 3 \mathrm{H}, \mathrm{CH}_{3},{ }^{3} \mathrm{~J}=6.6 \mathrm{~Hz}\right) \mathrm{ppm}$. ${ }^{13} \mathrm{C}-\mathrm{NMR},\left(125 \mathrm{MHz}, \mathrm{DMSO}-d_{6}\right): \delta=167.47,158.57$, $156.28,151.32,148.90,140.82,135.76,131.22,130.57$, $121.40,119.36,117.83,115.94,109.95,83.77,72.19$, $22.97 \mathrm{ppm}$. Elemental analysis (\%) found for $\mathrm{C}_{17} \mathrm{H}_{17} \mathrm{~N}_{3} \mathrm{O}_{3}$ : C, 65.55; H, 5.55; N, 13.54; O, 15.35. calcd.: C, 65.58; H, 5.50; N, 13.49; O, 15.42\%. MS (ESI, $70 \mathrm{eV}$ ): m/z calc. for $\mathrm{C}_{17} \mathrm{H}_{17} \mathrm{~N}_{3} \mathrm{O}_{3}[\mathrm{M}+\mathrm{H}]^{+}:$313.34, found 313.38. 


\section{Materials and methods}

\section{Chemicals}

All reagents and solvents (provided by Sigma-Aldrich) were used without any further purification.

\section{Evaluation of the antimicrobial activity Qualitative screening of the antimicrobial activity}

Standardized bacterial suspensions with a density of 1.5-3 $\times 10^{8} \mathrm{CFU} \mathrm{mL} \mathrm{mL}^{-1}$ (corresponding to the $0.5 \mathrm{McFar}$ land nephelometric standard) were obtained from 15 to $18 \mathrm{~h}$ fresh bacterial cultures developed on solid media. The compounds were suspended in DMSO to prepare a stock solution of $10 \mathrm{mg} \mathrm{mL}^{-1}$ concentration. The antimicrobial activity was tested on Mueller-Hinton Agar (MHA) medium. The qualitative screening was performed by an adapted disc diffusion method $[60,78]$.

\section{Quantitative assay of the antimicrobial activity}

The quantitative assay of the antimicrobial activity was performed by liquid medium microdilution method in 96 multi-well plates. Two-fold serial dilutions of the compounds solutions (ranging between $1000 \mathrm{mg}$ and $4 \mathrm{mg} \mathrm{mL}^{-1}$ ) were performed in a $200 \mathrm{~mL}$ volume of broth, and each was well seeded with $50 \mathrm{~mL}$ microbial inoculum. Bacterial culture positive controls (wells containing culture medium seeded with the microbial inoculum) as well negative sterility controls (containing only culture medium) were used. The influence of the DMSO solvent was also quantified in a series of wells containing DMSO, diluted accordingly with the dilution scheme used for the tested compounds. The multi-well plates were incubated for $24 \mathrm{~h}$ at $37^{\circ} \mathrm{C}$, and the minimal inhibitory concentration (MIC) values were considered as the lowest concentration of the tested compound that inhibited the visible growth of the microbial overnight cultures, as compared to the positive control, correlated with a decreased value of the absorbance read at $600 \mathrm{~nm}$ (by using an "Apollo LB 911" ELISA reader). All trials were performed in triplicate and the results were stated as mean.

\section{Quantitative assay of the anti-biofilm activity}

In order to evaluate the influence of the obtained compounds upon the colonization ability of microbial strains to the inert substratum, a microtiter method was employed. The multi-well plates used for the MIC assay were emptied and washed three times with phosphate buffered saline. The biofilm formed on the plastic wells wall. After it was fixed for 5 min with cold methanol and coloured for $15 \mathrm{~min}$ by violet crystal solution, it was resuspended in a $33 \%$ acetic acid solution. The minimal biofilm eradication concentration (MBEC) values were considered at the lowest concentration of the tested compound that inhibited the development of biofilm on the plate wells, as revealed by the decreased values of the optical density of the coloured solution at $490 \mathrm{~nm}$, and as compared to that of the positive control [72]. All trials were performed in triplicate and the results were stated as mean.

\section{Computational and modeling details}

A quantum mechanical modeling method was implemented for each benzimidazole compound, using the GAMESS 2012 software [79], in order to assess their structural parameters. The modeling was performed on a computer cluster consisting of 12 nodes and 96 cores running on Linux CentOS. The results were visualized using wxMacMolPlt [80]. The molecular geometries of the benzimidazoles were optimized by using DFT at M11/ktzvp level of theory. Truhlar's M11 [81] is a modern range-separated hybrid functional that provides better results compared to the traditional B3LYP functional class of approximations to the exchange correlation energy in DFT. Also, the basis set that we used is a more recent one (Karlsruhe valence triple zeta basis with a set of single polarization), introduced by Prof. Ahlrichs $[82,83]$. The parameters used for geometry optimization are the default ones used in GAMESS, and the geometry used during the calculations is described by "natural internal coordinates" generated by the software.

\section{Conclusions}

We reported here the synthesis and the characterization of a series of new chiral Mannich benzimidazole bases starting from (S)-1-(1H-benzo[d]imidazole-2-yl)ethanol (B). The analysis of their antimicrobial activity allowed us to determine that Mannich base M-1 shows the best antimicrobial activity expressed both as MIC value and as anti-biofilm activity. For all new compounds a better antifungal activity than the antimicrobial activity was reported. For all compounds, the calculated chemical reactivity indices were correlated with their antimicrobial behaviour. Molecules B and M-1 have superior antimicrobial activity, due to their structural characteristics, like: almost flat structure of the two molecules, higher hydrophobicities, minimum Mulliken charges on oxygen atom (from $\mathrm{OH}$ group) and lowest values of global electrophilicity indices (of 0.050 and 0.0527 , respectively). The compound M-4 shows the best values for the antibiofilm activity, of $0.030 \mu \mathrm{g} \mathrm{mL} \mathrm{m}^{-1}$ against Staphylococcus aureus and Candida albicans. The similar reactivities of the three compounds $\mathbf{M - 1}, \mathbf{M}-\mathbf{2}$ and $\mathbf{B}$ was related mainly with localization of HOMO-LUMO orbitals and with tridimensional structures of the molecules. The flatness of the molecule is an advantage for a good biological activity, as can be seen from the optimized geometries of the 
studied compounds, $\mathbf{M}-\mathbf{2}$ and $\mathbf{B}$. Similarly, the increased charges on heteroatoms in molecules $\mathbf{M - 1}, \mathbf{M}-\mathbf{2}$ and $\mathbf{M}-\mathbf{4}$, contribute to a better antimicrobial activity.

\section{Supplementary information}

Supplementary information accompanies this paper at https://doi. org/10.1186/s13065-020-00697-z.

Additional file 1: Fig. S1. Comparison of experimental and simulated IR spectra of the benzimidazole compounds: (a) Experimental FTIR spectra; (b) Simulated IR spectra. Fig. S2. FTIR spectra of Mannich base M-1. Fig. S3. FTIR spectra of Mannich base $\mathbf{M - 2}$. Fig. S4. FTIR spectra of Mannich base $\mathbf{M}-\mathbf{3}$. Fig. S5. FTIR spectra of Mannich base $\mathbf{M - 4}$. Fig. S6. FTIR spectra of Mannich base $\mathbf{M - 5}$. Table $\mathbf{S 1}$. Important infrared bands (in $\mathrm{cm}^{-1}$ ) of the benzimidazoles: B, $\mathbf{M}-\mathbf{1}-\mathbf{M}-\mathbf{5}$ (experimental and calculated). Fig. S7. ${ }^{1} \mathrm{H}$ NMR spectra of Mannich base $\mathbf{M}$-1. Fig. S8. ${ }^{13} \mathrm{C}$ NMR spectra of Mannich base $\mathbf{M}$-1. Fig. S9. ${ }^{1} \mathrm{H}$ NMR spectra of Mannich base $\mathbf{M}-\mathbf{2}$. Fig. $\mathbf{S 1 0} .{ }^{13} \mathrm{C}$ NMR spectra of Mannich base $\mathbf{M}-\mathbf{2}$. Fig. S11. ${ }^{1} \mathrm{H}$ NMR spectra of Mannich base $\mathbf{M}$-3. Fig. S12. ${ }^{13} \mathrm{C}$ NMR spectra of Mannich base $\mathbf{M}-\mathbf{3}$. Fig. S13. ${ }^{1} \mathrm{H}$ NMR spectra of Mannich base $\mathbf{M}-\mathbf{4}$. Fig. S13. ${ }^{1} \mathrm{H}$ NMR spectra of Mannich base $\mathbf{M - 4}$. Fig. S14. ${ }^{13} \mathrm{C}$ NMR spectra of Mannich base $\mathbf{M - 4}$. Fig. S15. ${ }^{1} \mathrm{H}$ NMR spectra of Mannich base M-5. Fig. S16. 13C NMR spectra of Mannich base $\mathbf{M}-\mathbf{5}$

\section{Abbreviations}

DFT: Density functional theory; NMR: Nuclear magnetic resonance; FTIR: Fourrier transform infra-red; HPLC: High-performance liquid chromatography; HOMO: The highest occupied molecular orbital; LUMO: The lowest unoccupied molecular orbital; MIC: Minimum inhibitory concentration; MBEC: Minimum biofilm eradication concentration; MBSC: Multiband superconducting model.

\section{Acknowledgements}

Not applicable.

\section{Authors' contributions}

MM performed the organic syntheses, conceptualization, and writing-original; LOC and GIM performed QM calculations (DFT); MCC and MP performed the biological analysis; IS and CMZ recorded the FTIR spectra; CES recorded the NMR spectra. Each contributor was essential to the production of this work. All authors read and approved the final manuscript.

\section{Funding}

This work was supported by a grant of the Romanian National Authority for Scientific Research and Innovation, CNCS/CCCDI-UEFISCDI, Project Number PN-III-P2-2.1-BG-2016-0142, within PNCDI III. The funding body used in the study design, data collection and analysis.

\section{Availability of data and materials}

The datasets and samples of the compounds used during the current study are available from the corresponding author on reasonable request.

\section{Competing interests}

The authors declare that they have no competing interests.

\section{Author details}

${ }^{1}$ Department of Organic Chemistry, Biochemistry and Catalysis, Faculty of Chemistry, University of Bucharest, Bucharest 050663, Romania. ${ }^{2}$ Department of Physical Chemistry, Faculty of Chemistry, University of Bucharest, Bucharest 030018, Romania. ${ }^{3}$ Faculty of Applied Chemistry and Materials Science, University "Politehnica" of Bucharest, 1-7 Polizu, 011061 Bucharest, Romania. ${ }^{4}$ Department of Botanic-Microbiology, Faculty of Biology, University of Bucharest, 1-3 Aleea Portocalilor, 60101 Bucharest, Romania. ${ }^{5}$ Research Institute of the University of Bucharest, 91-95 Splaiul Independentei, 050095 Bucharest, Romania. ${ }^{6}$ Institute of Organic Chemistry "C.D. Nenitzescu" of the Romanian Academy, 202B Splaiul Independentei, 060023 Bucharest, Romania.
Received: 5 March 2020 Accepted: 10 July 2020

Published online: 25 July 2020

\section{References}

1. Plech T, Wujek M, Siwek A, Kosikowska U, Malm A (2011) Synthesis and antimicrobial activity of thiosemicarbazides, s-triazoles and their Mannich bases bearing 3-chlorophenyl moiety. Eur J Med Chem 46(1):241-248

2. Kumar SV, Subramanian MR, Chinnaiyan SK (2013) Synthesis, characterization and evaluation of N-Mannich bases of 2-substituted benzimidazole derivatives. J Young Pharmacists 5(4):154-159

3. Frank PV, Poojary MM, Damodara N, Chikkanna C (2013) Synthesis and antimicrobial studies of some Mannich bases carrying imidazole moiety. Acta Pharm 63(2):231-239

4. Jose G, Kumara THS, Sowmya HBW, Sriram D, Row TNG, Hosamani AA, More SS, Janardhan B, Harish BG, Telkar S, Ravikumar YS (2017) Synthesis, molecular docking, antimycobacterial and antimicrobial evaluation of new pyrrolo[3,2-c]pyridine Mannich bases. Eur J Med Chem 131:275-288

5. Wang B, Zhang LY, Liu XH, Ma Y, Zhang Y, Li ZM, Zhang X (2017) Synthesis, biological activities and SAR studies of new 3-substitutedphenyl-4-substitutedbenzylideneamino -1,2,4-triazole Mannich bases and bis-Mannich bases as ketol-acid reductoisomerase inhibitors. Bioorg Med Chem Lett 27(24):457-5462

6. Marinescu M, Tudorache DG, Marton Gl, Zalaru CM, Popa M, Chifiriuc MC, Stavarache CE, Constantinescu C (2017) Density functional theory molecular modeling, chemical synthesis, and antimicrobial behaviour of selected benzimidazole derivatives. J Mol Struct 1130:463-471

7. Zalaru C, Dumitrascu F, Draghici C, Tarcomnicu I, Tatia R, Moldovan L, Chifiriuc MC, Lazar V, Marinescu M, Nitulescu MG, Ferbinteanu M (2018) Synthesis, spectroscopic characterization, DFT study and antimicrobial activity of novel alkylaminopyrazole derivatives. J Mol Struct 1156:12-21

8. Liu Y, Xin H, Yin J, Yin D, Yang Z, Li J (2018) Synthesis of novel ferrocenyl Mannich bases and their antibacterial activities. J Mol Struct 1157:482-485

9. Roman G (2015) Mannich bases in medicinal chemistry and drug design. Eur J Med Chem 89:743-816

10. Pandeya SN, Sriram D, Nath G, De Clercq E (1999) Synthesis, antibacterial, antifungal and anti-HIV evaluation of Schiff and Mannich bases of isatin derivatives with 3-amino-2-methylmercapto quinazolin-4(3H)-one. Pharm Acta Helvet 74(1):11-17

11. Jesudason EP, Sridhar SK, Padma Malar EJ, Shanmugapandiyan P, Inayathullah M, Arul V, Selvaraj D, Jayakumar R (2009) Synthesis, pharmacological screening, quantum chemical and in vitro permeability studies of $\mathrm{N}-$ Mannich bases of benzimidazoles through bovine cornea. Eur J Med Chem 44(5):2307-2312

12. Sujith KV, Rao JN, Shetty P, Kalluraya B (2009) Regioselective reaction: synthesis and pharmacological study of Mannich bases containing ibuprofen moiety. Eur J Med Chem 44(9):3697-3702

13. Datar PA, Limaye SA (2015) Design and synthesis of Mannich bases as benzimidazole derivatives as analgesic agents. Antiinflamm Antiallergy Agents Med Chem 14(1):35-46

14. Mariappan G, Bhuyan NR, Kumar P, Kumar D, Murali K (2011) Synthesis and biological evaluation of Mannich bases and benzimidazole derivatives. Ind J Chem 50B(09):1216-1219

15. Bala S, Sharma N, Kajal A, Kamboj S, Saini V (2014) Mannich bases: an important pharmacophore in present scenario. Int J Med Chem 2014:191072

16. Alpan AS, Sarıkaya G, Coban G, Parlar S, Armagan G, Alptuzun V (2017) Mannich-benzimidazole derivatives as antioxidant and aceticholinesterase inhibitors: synthesis, biological evaluations and molecular docking study. Arch Pharm Chem Life Sci 350(7):e1600351

17. Fernández-Bachiller MI, Pérez C, González-Muñoz GC, Conde S, López MG, Villarroya M, García AG, Rodríguez-Franco MI (2010) Novel tacrine8-hydroxyquinoline hybrids as multifunctional agents for the treatment of Alzheimer's disease, with neuroprotective, cholinergic, antioxidant, and copper-complexing properties. J Med Chem 53(13):4927-4937

18. Tao D, Wang Y, Bao XQ, Yang BB, Gao F, Wang L, Zhang D, Li L (2019) Discovery of coumarin Mannich base derivatives as multifunctional agents against monoamine oxidase $B$ and neuroinflammation for the treatment of Parkinson's disease. Eur J Med Chem 173:203-212 
19. Al-Abdullah ES, Al-Tuwaijiri HM, Hassan HM, Haiba ME, Habib EE, El-Emam AA (2014) Antimicrobial and hypoglycemic activities of novel N-Mannich bases derived from 5-(1-adamantyl)-4-substituted-1,2,4-triazoline3-thiones. Int J Mol Sci 15(12):22995-23010

20. Marinescu M (2019) Introductory chapter: Short insight in synthesis and applications of benzimidazole and its derivatives. In: Marinescu M (ed) Chemistry and applications of benzimidazole and its derivatives. IntechOpen, London, pp 1-12

21. Panda SS, Malik R, Jain SC (2012) Synthetic approaches to 2-arylbenzimidazoles: a review. Curr Org Chem 16(16):1905-1919

22. Bansal Y, Silakari O (2012) The therapeutic journey of benzimidazoles: a review. Bioorg Med Chem 20(21):6208-6236

23. Keri RS, Rajappa CK, Patil SA, Nagaraja BM (2016) Benzimidazole-core as an antimycobacterial agent. Pharmacol Rep 68(6):1254-1265

24. Liu T, Sun C, Xing X, Jing L, Tan R, Luo Y, Huang W, Song H, Li Z, Zhao Y (2012) Synthesis and evaluation of 2-[2-(phenylthiomethyl)-1 H-benzo[d] imidazol-1-yl)acetohydrazide derivatives as antitumor agents. Bioorg Med Chem Lett 22(9):3122-3125

25. Marinescu M (2019) Chemistry and applications of benzimidazole and its derivatives. Intechopen, London, pp 89-156

26. Guo C, Linton A, Jalaie M, Kephart S, Ornelas M, Pairish M, Greasley S, Richardson P, Maegley K, Hickey M, Li J, Wu X, Ji X, Xie Z (2013) Discovery of 2- ((1H-benzo[d]imidazol-1-yl)methyl)-4H-pyrido[1,2-a]pyrimidin-4-ones as novel PKM2 activators. Bioorg Med Chem Lett 23(11):3358-3363

27. Yoon YK, Ali MA, Wei AC, Shirazi AN, Parang K, Choon TS (2014) Benzimidazoles as new scaffold of sirtuin inhibitors: green synthesis, in vitro studies, molecular docking analysis and evaluation of their anti-cancer properties. Eur J Med Chem 83:448-454

28. Nakao S, Mabuchi M, Shimizu T, Itoh Y, Takeuchi Y, Ueda M, Mizuno H, Shigi N, Ohshio I, Jinguji K, Ueda Y, Yamamoto M, Furukawa T, Aoki S, Tsujikawa K, Tanaka A (2014) Design and synthesis of prostate cancer antigen-1 (PCA-1/ALKBH3) inhibitors as anti-prostate cancer drugs. Bioorg Med Chem Lett 24(4):1071-1074

29. Tahlan S, Kumar S, Kakkar S, Narasimhan B (2019) Benzimidazole scaffolds as promising antiproliferative agents: a review. BMC Chemistry 13:66

30. Tahlan S, Kumar S, Ramasamy K, Lim SM, Shah SAA, Mani V, Narasimhan B (2019) In-silico molecular design of heterocyclic benzimidazole scaffolds as prospective anticancer agents. BMC Chemistry 13:90

31. Tahlan S, Kumar S, Ramasamy K, Lim SM, Shah SAA, Mani V, Pathania R, Narasimhan B (2019) Design, synthesis and biological profile of heterocyclic benzimidazole analogues as prospective antimicrobial and antiproliferative agents. BMC Chem 13:50

32. Cheong JE, Zaffagni M, Chung I, Xu Y, Wang Y, Jernigan FE, Zetter BR, Sun $L$ (2018) Synthesis and anticancer activity of novel water soluble benzimidazole carbamates. Eur J Med Chem 144:372-385

33. Bistrovic A, Krstulovic L, Harej A, Grbcic P, Sedic M, Kostrun S, Pavelic SK, Bajic M, Raic-Malic S (2018) Design, synthesis and biological evaluation of novel benzimidazole amidines as potent multi-target inhibitors for the treatment of non-small cell lung cancer. Eur J Med Chem 143:1616-1634

34. Tahlan S, Kumar S, Narasimhan B (2019) Antimicrobial potential of 1H-benzo[d]imidazole scaffold: a review. BMC Chem 13:18

35. Zhang H-Z, He S-C, Peng Y-J, Zhang H-J, Gopala L, Tangadanchu VKR, Gan L-L, Zhou C-H (2017) Design, synthesis and antimicrobial evaluation of novel benzimidazole-incorporated sulfonamide analogues. Eur J Med Chem 136:165-183

36. Yadav S, Lim SM, Ramasamy K, Vasudevan M, Shah SAA, Mathur A, Narasimhan B (2018) Synthesis and evaluation of antimicrobial, antitubercular and anticancer activities of 2-(1-benzoyl -1 H -benzo[d]imidazol2-ylthio)-N-substituted acetamides. Chem Cent J 12:66

37. Liu H-B, Gao W-W, Tangadanchu VKR, Zhou C-H, Geng R-X (2018) Novel aminopyrimidinyl benzimidazoles as potentially antimicrobial agents: design, synthesis and biological evaluation. Eur J Med Chem 143:66-84

38. Padhy GK, Panda J, Behera AK (2017) Synthesis and characterization of novel benzimidazole embedded 1,3,5-trisubstituted pyrazolines as antimicrobial agents. J Serb Chem Soc 82(9):985-993

39. Márquez-Navarro A, Nogueda-Torres B, Hernández-Campos A, SoriaArteche O, Castillo R, Rodríguez-Morales S, Yépez-Mulia L, HernándezLuis F (2009) Anthelmintic activity of benzimidazole derivatives against Toxocara canis second-stage larvae and Hymenolepis nana adults. Acta Trop 109(3):232-235
40. Hadole CD, Rajput JD, Bendre RS (2018) Concise on some biologically important 2-substituted benzimidazole derivatives. Curr Chem Curr Res 7:3

41. Shin JM, Kim N (2013) Pharmacokinetics and pharmacodynamics of the proton pump inhibitors. J Neurogastroenterol Motil 19(1):25-35

42. Gaba M, Singh S, Mohan C (2014) Benzimidazole: an emerging scaffold for analgesic and anti-inflammatory agents. Eur J Med Chem 76:495-505

43. Bansal Y, Kaur M, Silakari O (2015) Benzimidazole-ibuprofen/mesalamine conjugates: potential candidates for multifactorial diseases. Eur J Med Chem 89:671-682

44. Zhu W, Bao X, Ren H, Da Y, Wu D, Li F, Yan Y, Wang L, Chen Z (2016) $\mathrm{N}$-Phenyl indole derivatives as AT1 antagonists with anti-hypertension activities: design, synthesis and biological evaluation. Eur J Med Chem 115:161-178

45. Kim TH, Yang HY, Park BG, Jung SY, Park JH, Park KD, Min SJ, Tae J, Yang H, Cho S, Cho SJ, Song H, Moong-Jung I, Lee J, Pae AN (2017) Discovery of benzimidazole derivatives as modulators of mitochondrial function: a potential treatment for Alzheimer's disease. Eur J Med Chem 125:1172-1192

46. Cheretaev IV, Korenyuk V, Nozdrachev AD (2018) Neurotropic, psychoactive, and analgesic properties of benzimidazole and its derivatives: physiological mechanisms. Neurosci Behav Physiol 48(7):848-853

47. Kumbhar SS, Choudhari PB (2017) 3D QSAR and pharmacophore modelling of selected benzimidazole derivatives as factor IXa inhibitors. Ind J Pharm Sci 79(5):813-819

48. Aboul-Enein HY, El Rashedy AA (2015) Benzimidazole derivatives as antidiabetic agents. Med Chem 5(7):318-325

49. Celik I, Ayhan-Kilcigil G, Guven B, Kara Z, Gurkan-Alp AS, Karayel A, OnayBesikci A (2019) Design, synthesis and docking studies of benzimidazole derivatives as potential EGFR inhibitors. Eur J Med Chem 173:240-249

50. Akhtar MJ, Siddiqui AA, Khan AA, Ali Z, Dewangan RP, Pasha S, Yar MS (2017) Design, synthesis, docking and QSAR study of substituted benzimidazole linked oxadiazole as cytotoxic agents, EGFR and erbB2 receptor inhibitors. Eur J Med Chem 126:853-869

51. Ding Y, Chai J, Centrella PA, Gondo C, DeLorey JL, Clark MA (2018) Development and synthesis of DNA-encoded benzimidazole library. ACS Comb Sci 20(5):251-255

52. Popov AB, Stolic I, Krstulovic L, Taylor MC, Kelly JM, Tomic S, Tumir L, Bajic M, Raić-Malić S (2019) Novel symmetric bis-benzimidazoles: synthesis, DNA/RNA binding and antitrypanosomal activity. Eur J Med Chem 173:63-75

53. El-Gohary NS, Shaaban MI (2017) Synthesis, antimicrobial, antiquorumsensing and antitumor activities of new benzimidazole analogs. Eur J Med Chem 137:439-449

54. Brown AD, Bagal SK, Blackwell P, Blakemore DC, Brown B, Bungay PJ, Corless M, Crowforth J, Fengas D, Fenwic DR, Gray V, Kemp M, Klute W, Sanz LM, Miller D, Murata Y, Payne CE, Skerratt S, Stevens EB, Warmus JS (2019) The discovery and optimization of benzimidazoles as selective $\mathrm{Na}_{\mathrm{V}} 1.8$ blockers for the treatment of pain. Eur J Med Chem 27:230-239

55. Pan T, He X, Chen B, Chen H, Gheng G, Luo H, Zhang H, Bai C (2015) Development of benzimidazole derivatives to inhibit HIV-1 replication through protecting APOBEC3G protein. Eur J Med Chem 95:500-513

56. Hameed A, Hameed A, Farooq T, Noreen R, Javed S, Batool S, Ahmad A, Gulzar T, Ahmad M (2019) Evaluation of structurally different benzimidazoles as priming agents, plant defence activators and growth enhancers in wheat. BMC Chem 13:29

57. Bernardi L, Hothelf AS, Hazell RG, Jorgensen KA (2003) Catalytic asymmetric Mannich reactions of glycine derivatives with imines. A new approach to optically active $a, \beta$-diamino acid derivatives. J Org Chem 68:2583-2591

58. Ibrahem I, Zou W, Engqvist M, Xu Y, Cordova A (2005) Acyclic chiral amines and amino acids as inexpensive and readily tunable catalysts for the direct asymmetric three-component Mannich reaction. Chem Eur J 11:7024-7029

59. Guo QX, Liu H, Guo C, Luo SW, Gu Y, Gong LZ (2007) Chiral Brønsted acid-catalyzed direct asymmetric Mannich reaction. J Am Chem Soc 129:3790-3791

60. Bhaduri PS, Song BA (2010) Chemistry of organocatalytic asymmetric Mannich reactions. Curr Org Chem 14:1989-2006

61. Cai XH, Xie B (2013) Recent advances on organocatalysed asymmetric Mannich reactions. ARKIVOC 2013(i):264-293 
62. Dai J, Xiong D, Yuan T, Liu J, Chen T, Shao Z (2017) Chiral primary amine catalysis for asymmetric Mannich reactions of aldehydes with ketimines: stereoselectivity and reactivity. Angew Chem Int Ed 56:12697-12701

63. Buchcic A, Zawisza A, Lesniak S, Adamczyk J, Pieczonka AM, Rachwalski M (2019) Enantioselective Mannich reaction promoted by chiral phosphinoyl-aziridines. Catalysts 9:837

64. Kumar GR, Ramesh B, Yarlagadda S, Sridhar B, Subba Reddy BV (2019) Organocatalytic enantioselective Mannich reaction: direct access to chiral B-amino esters. ACS Omega 4:2168-2177

65. Lu J, Fan Y, Sha F, Li Q, Wu XY (2019) Copper-catalyzed enantioselective Mannich reaction between $\mathrm{N}$-acylpyrazoles and isatinderived ketimines. Org Chem Front 6:2687-2691

66. Xue Y, Li LP, He YH, Guan Z (2012) Protease-catalysed direct asymmetric Mannich reaction in organic solvent. Sci Rep 2:761

67. Lian X, Lin L, Fu K, Ma B, Liu X, Feng X (2017) A new approach to the asymmetric Mannich reaction catalyzed by chiral N, N'-dioxide-metal complexes. Chem Sci 8:1238

68. Maghsoodlou MT, Mousavi SR, Roygar A, Lashkari M (2018) Three-component carbon-carbon bond-forming reactions for the synthesis $\beta$-amino carbonyl compounds using maleic acid-catalyzed one-pot Mannich-type reaction in ethanol. Kragujevac J Sci 40:71-81

69. Gao WW, Gopala L, Bheemanaboina RRY, Zhang GB, Li S, Zhou CH (2018) Discovery of 2-aminothiazolyl berberine derivatives as effectively antibacterial agents toward clinically drug-resistan Gram-negative Acinetobacter baumanii. Eur J Med Chem 146:15-37

70. Ion V, Matei A, Constantinescu C, Mitu B, lonita I, Marinescu M, Dinescu M, Emandi A (2015) Octahydroacridine thin films grown by matrix-assisted pulsed laser evaporation for non linear optical applications. Mat Sci Semicon Proc 36:78-83

71. Zalaru C, Dumitrascu F, Draghici C, lovu M, Marinescu M, Tarcomnicu I, Nitulescu GM (2014) Synthesis and biological screening of some novel 2-(1 H-pyrazol-1-yl)-acedamides as lidocaine analogue. Ind J Chem 53B(6):733-739

72. Marinescu M, Cinteza LO, Marton Gl, Marutescu LG, Chifiriuc MC, Constantinescu C (2017) Density functional theory molecular modeling and antimicrobial behaviour of selected 1,2,3,4,5,6,7,8-octahydroacridineN(10)-oxides. J Mol Struct 1144:14-23
73. Marinescu M, Emandi A, Marton G, Cinteza LO, Constantinescu C (2015) Structural studies and optical nonlinear response of some pyrazole5-ones. Nanosci Nanotechnol Lett 7(10):846-854

74. Matei A, Marinescu M, Constantinescu C, Ion V, Mitu B, lonita I, Dinescu M, Emandi A (2016) Nonlinear optical studies on 4-(ferrocenylmethylimino)2-hydroxy-benzoic acid thin films deposited by matrix-assisted pulsed laser evaporation (MAPLE). Appl Surf Sci 374:206-212

75. Soltani A, Javan MB, Raz SG, Mashkoor R, Khalaji AD, Dusek M, Fejfarova K, Palatinus L, Rohlicek J, Machek P (2018) Crystallography, vibrational, electronic and optical analysis of 4-bromo-2-(2,5-dichloro-phenylimino)phenol. J Mol Struct 1173:521-530

76. Pearson RG (2005) Chemical hardness and density functional theory. J Chem Sci 117(5):369-377

77. Pearson PK (1993) Principle of maximum hardness. Acc Chem Res 26(5):250-255

78. Ciobanu CS, Iconaru SL, Chifiriuc MC, Costescu A, Coustumer PL, Predoi D (2013) Synthesis and antimicrobial activity of silver-doped hydroxyapatite nano-particles. Biomed Res Int 2013:916218

79. Schmidt MW, Baldridge KK, Boatz JA, Elbert ST, Gordon MS, Jensen JH, Koseki S, Matsunaga N, Nguyen KA, Su S, Windus TL, Dupuis M, Montgomery JA (1993) General atomic and molecular electronic structure system. J Comput Chem 14(11):1347-1363

80. Bode BM, Gordon MS (1998) Macmolplt: a graphical user interface for GAMESS. J Mol Graph Mod 16(3):133-138

81. Peverati R, Truhlar DG (2011) Improving the accuracy of hybrid meta-GGA density functionals by range separation. J Phys Chem Lett 2(21):2810-2817

82. Schaefer A, Horn H, Ahlrichs R (1992) Fully optimized contracted Gaussian basis sets for atoms Li to Kr. J Chem Phys 97(4):2571-2577

83. Schaefer A, Horn H, Ahlrichs R (1994) Fully optimized contracted Gaussian basis sets of triple zeta valence quality for atoms Li to Kr. J Chem Phys 100(8):5829-5835

\section{Publisher's Note}

Springer Nature remains neutral with regard to jurisdictional claims in published maps and institutional affiliations.
Ready to submit your research? Choose BMC and benefit from:

- fast, convenient online submission

- thorough peer review by experienced researchers in your field

- rapid publication on acceptance

- support for research data, including large and complex data types

- gold Open Access which fosters wider collaboration and increased citations

- maximum visibility for your research: over 100M website views per year

At $\mathrm{BMC}$, research is always in progress.

Learn more biomedcentral.com/submissions 